\title{
Lockdown botany 2020: some noteworthy records of alien plants in Kyiv City and Kyiv Region
}

\author{
Sergei L. MOSYAKIN ${ }^{1 *} \mathbb{D}$, Andrii S. MOSYAKIN ${ }^{2}$ \\ ${ }^{1}$ M.G. Kholodny Institute of Botany, National Academy of Sciences of Ukraine, 2 Tereschenkivska Str., Kyiv 01601, Ukraine \\ ${ }^{2}$ Ukrainian Botanical Society, 2 Tereschenkivska Str., Kyiv 01601, Ukraine
}

\begin{abstract}
Noteworthy records of 11 alien plant species in Kyiv City and Kyiv Region made mainly in 2020 are discussed. In particular, new localities of the following taxa are reported: Amaranthus spinosus, Artemisia tournefortiana, Chenopodium ucrainicum, Celastrus orbiculatus, Datura innoxia, Dysphania ambrosioides, Erechtites hieraciifolius, Mesembryanthemum $\times$ vascosilvae $(M$. cordifolium $\times$ M. haeckelianum; recently described as Aptenia $\times$ vascosilvae and reported here for the first time for Ukraine; earlier this ornamental hybrid was misidentified as Aptenia cordifolia), Parietaria officinalis, Phytolacca americana, Thladiantha dubia. The presence in Ukraine of several additional species, such as Datura wrightii and Phytolacca acinosa s.l. (incl. P. esculenta), that may occur as escaped near places of their cultivation, is reported; these species may be confused with $D$. innoxia and $P$. americana, respectively. The growing role of alien plants escaped from cultivation (ergasiophytes) in the present-day processes of formation of the alien flora of Ukraine is emphasized.
\end{abstract}

Keywords: alien plants, Amaranthus, Artemisia, Celastrus, Chenopodium, Datura, Dysphania, Erechtites, flora, Kyiv, Mesembryanthemum, Phytolacca, Ukraine

Supplementary Material. Electronic Supplement (Figures E1-E6, e1-e3) is available in the online version of this article at: https://ukrbotj.co.ua/archive/78/2/096

Article history. Submitted 12 March 2021. Revised 26 March 2021. Published 30 April 2021

Citation. Mosyakin S.L., Mosyakin A.S. 2021. Lockdown botany 2020: some noteworthy records of alien plants in Kyiv City and Kyiv Region. Ukrainian Botanical Journal, 78(2): 96-111. https://doi.org/10.15407/ukrbotj78.02.096

*Corresponding author (e-mail: s_mosyakin@,hotmail.com)

\section{Introduction}

The SARS-CoV-19 coronavirus quarantine restrictions (in particular, several quarantine and lockdown phases) introduced in Ukraine in 2020 dramatically disrupted fieldwork plans of Ukrainian botanists. However, even under these restrictions we had some limited opportunities to survey selected areas in Kyiv City and Kyiv Region during our short-term visits and/or field trips. These visits and trips resulted in discoveries of several new localities of alien species, thus documenting their further spread in the northern-central part of Ukraine. These new floristic records are reported here. In several cases, when appropriate, we also mentioned our earlier floristic finds and herbarium collections made before 2020. Selected field photographs in the printed version of the present article are provided to assist better identification of plants and to illustrate their spread and participation in plant communities. Additional photographs are available from the Electronic Supplement. Images in the Electronic Supplement are numbered with the prefix E. For many records reported here, additional images of plants and their habitats are available online from iNaturalist (https://www.inaturalist.org/; observations of the user sergei_mosyakin). Voucher herbarium specimens are deposited at the National Herbarium of Ukraine (KW, M.G. Kholodny Institute of Botany, National Academy of Sciences of Ukraine, Kyiv, Ukraine). The herbarium acronyms here and below are given following Index Herbariorum (Thiers, 2008-onward).

(C) 2021 S.L. Mosyakin, A.S. Mosyakin. Published by the M.G. Kholodny Institute of Botany, NAS of Ukraine. This is an open access article under the terms of the Creative Commons Attribution License (http://creativecommons.org/licenses/by/4.0/), which permits use, distribution, and reproduction in any medium, provided the original work is properly cited 


\section{New localities of alien species}

\section{Amaranthus spinosus L. (Amaranthaceae s. str.)}

This morphologically distinctive species is native to South America but at present it is rather widespread in many tropical, subtropical and partly warm temperate regions of the world (Mosyakin, Robertson, 2003; Bayón, 2015). Taxonomically it is considered to be the sole member of Amaranthus L. sect. Centrusa Griseb. (= sect. Acanthophora Beck) (see Mosyakin, Robertson, 1996, 2003) and phylogenetically it is placed in the earlybranching subclade of the Hybridus clade (Waselkov et al., 2018). In Ukraine it was reported earlier in Kyiv as an occasional non-established garden escape in the M.M. Gryshko National Botanical Garden (NBG) of the National Academy of Sciences of Ukraine, mainly at the New Crops collection plots (Mosyakin, 1991, 1995a, b, 1996; Shynder, 2019b) and as a rare non-established railway alien in Donetsk (Kondratyuk et al., 1987; Mosyakin, 1995a, 1996).

In 2020 we discovered a small group of several plants in a weedy roadside spot along the Kyiv-Odesa highway at the northern limit of the settlement of Hlevakha, near a small shopping plaza with a FORA supermarket, several smaller shops (including one shop selling nuts, dried fruits, canned food and other kinds of food, mainly those imported from Turkey, Iran, China, countries of the Caucasus, etc.), and a restaurant. In order to prevent possible further spread of that dangerous weed in the area, we collected all plants of $A$. spinosus seen; some plants and plant fragments were lodged as herbarium specimens (now in $\mathrm{KW}$ ) while other plant material was destroyed. The precise location information is provided below.

Kyiv Region, Fastiv District, northern part of Hlevakha (alternative transliterations: Glevaha or Glevakha), a shopping area between the M05 Kyiv-Odesa highway and Hrushevsky (alternative transliteration: Grushevskiy) Street, near the FORA supermarket, ruderal habitats along the roadside ditch. Coordinates: N 50.280201, E 30.344623. Observed and collected by S. Mosyakin and A. Mosyakin on 19 September and 4 October 2020 (Figs. 1, A, B).
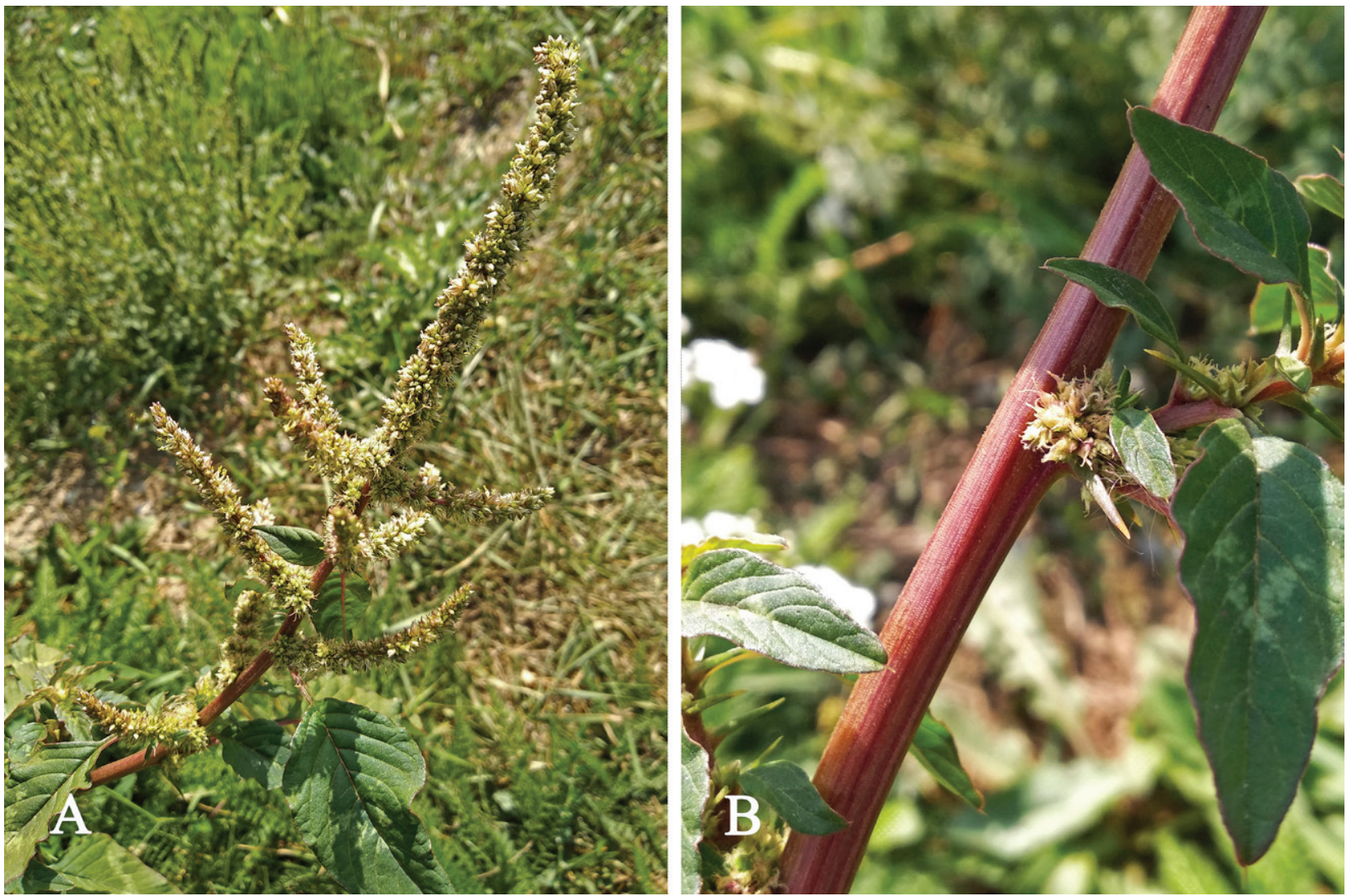

Fig. 1. Amaranthus spinosus, Kyiv Region, Hlevakha, 19 September 2020. A: the upper part of the plant; B: close-up 


\section{Artemisia tournefortiana Rchb. (Asteraceae)}

This species was repeatedly reported from several localities in Kyiv Region and Kyiv City (Mosyakin, 1990, 1992; Boiko, 2009, etc.), where it occurred mostly along railroads, highways, and near grain processing and transit facilities. However, sometimes groups of that species are found, rather unpredictably, in streets even in the central part of the city of Kyiv. For example, several years ago (2017) Sergei Mosyakin and then Ganna Boiko observed small groups of $A$. tournefortiana growing near walls at the crossroad of Taras Shevchenko Boulevard and Mykhaylo Kotsiubynskyi Street, across the boulevard from the O.V. Fomin Botanical Garden in the central part of the city (coordinates: N 50.445419, E 30.503197); however, the species was not registered or observed in the garden. After just two years or so the plants there disappeared. In 2020, groups of A. tournefortiana were found at ruderal sites and near walls of temporarily abandoned (under reconstruction) buildings on both sides of Turgenevska Street between Bulvarno-Kudriavska and Pavlivska streets (27 July 2020 and several later dates; coordinates N 50.450113, E 30.493319, Fig. E1). Several plants of $A$. tournefortiana were also found in the Lukianivka neighborhood along the city tram line connecting the central railway station and a popular farmer's market where fruits and vegetables from the southern regions of Ukraine and from Moldova are sold (9 July 2020; coordinates N 50.459168, E 30.484592).

\section{Chenopodium ucrainicum Mosyakin \& Mandák (Chenopodiaceae)}

This recently described diploid species was until recently reliably reported from three localities in Kyiv City, several places in Hrebinky (also sometimes transliterated as Grebinky), Kyiv Region, and at least one locality in Ostrog, Rivne Region (Mosyakin, Mandák, 2020). We have found an additional locality in Salyvonky, Kyiv Region, quite close to the first recorded site in Hrebinky. Interesting enough, the plants were still green on 21 and 22 November 2020 (Fig. 2), when most plants of other species of Chenopodium occurring in the area were already dry or frostbitten. The alien versus native status of this species in Ukraine remains questionable; however, we assumed (Mosyakin, Mandák, 2020) that it could be alien here and related to some insufficiently known morphotypes of Chenopodium from southern and eastern parts of Asia. The precise new location data are provided below.

Kyiv Region, Bila Tserkva District (formerly, before "decentralization" of July 2020 - Vasyl'kiv District), Salyvonky, ruderal sites under willow trees and along fences. Coordinates: N 49.939310, E 30.211648 . Observed and collected on 21 and 22 November 2020 by S. Mosyakin and A. Mosyakin.

\section{Celastrus orbiculatus Thunb. (Celastraceae)}

Celastrus orbiculatus, native to East Asia (Zhang, Funston, 2008), is considered to be a highly invasive species in North America (Leicht-Young et al., 2007; Pavlovic et al., 2007; Zaya et al., 2015, 2017; etc.), Europe (see Gudžinskas et al., 2017, 2020, and references therein) and some other parts of the world (e.g., New Zealand: Williams, Timmins, 2003). In North America that introduced species can hybridize with its native congener $C$. scandens L. (Pooler et al., 2002; Zaya et al., 2015). Naturalized populations of North American C. scandens were also reported in Ukraine (Tyshchenko et al., 2013). Earlier, Tzvelev (2004a: 449) reported C. orbiculatus and C. scandens for Eastern Europe only as plants rarely cultivated in gardens and parks.

We observed several large colonies of completely naturalized $C$. orbiculatus in the forest of PushchaVodytsya (in the northwestern part of Kyiv) since 2010, in particular in August 2010 and October 2012 (see Fig. 3), and since then collected and observed that species there several times during our excursions to the area. Groups of plants were also observed in 2020 in several parts of this forest. Detailed information on patterns of distribution and naturalization of $C$. orbiculatus in the forests in and near Kyiv was collected during recent years by Olena Vakarenko, who will provide that information in a special article (in preparation).

\section{Datura innoxia Mill. and related or similar species (Solanaceae)}

In many publications on the flora of Ukraine, only one species of Datura L., D. stramonium L., is reported (e.g., Prokudin et al., 1987), sometimes with D. tatula L. (now considered conspecific with $D$. stramonium). Three ornamental taxa (D. innoxia Mill., D. metel L. and D. meteloides DC. ex Dunal) were also reported as rare escapes from cultivation (e.g., Mosyakin, Fedoronchuk, 1999). In some publications D. stramonium was considered to be an archaeophyte in Ukraine (as well as in Europe in general). However, Symon and Haegi (1991) rather convincingly demonstrated that Datura is a New World genus and thus all of its species are of American origin, even if we accept that at least one species (domesticated D. metel) was introduced from the Americas to the Old World in pre-Columbian times, probably in the first millennium CE (Geeta, Gharaibeh, 2007).

Ukrainian Botanical Journal, 2021, 78(2) 
Datura innoxia (originally published as "inoxia" and sometimes still cited with that spelling of the species epithet, correctable under Art. 60.1 of the ICN: Turland et al., 2018) was reported in Ukraine as a cultivated ornamental plant, which until recently was planted mainly in the southern regions of the country, where it sometimes occurred as escaped (e.g., Boiko, Kolomiychuk, 2015); it is also known in many regions of Europe (e.g., Clement, 1998a; Verloove, 2006, 2008; Gudžinskas, 2017; Lakušić et al., 2017; Maslo, Šarić, 2019, and references therein). However, a closely related species, D. wrightii Regel (D. innoxia auct. non Mill., p.p.), native to the southwestern part of the United States and adjacent Mexico, is also cultivated in countries of Europe and some other regions of the world, where it occasionally occurs as escaped (see Clement, 1998a; Verloove, 2008; Verloove et al., 2010; Sáez et al., 2015; Buono et al., 2018; El Mokni, 2019, and references therein). It is morphologically similar to D. innoxia and may be confused for it. The main distinguishing characters of $D$. wrightii are their stem/branch pubescence (dense erect glandular trichomes in D. innoxia and short appressed eglandular hairs, sometimes intermixed with longer hairs in D. wrightii) and several characters of flowers, fruits and seeds (see Barclay, 1959; Haegi, 1976, Luna Cavazos et al., 2000, etc.; summarized by Verloove, 2008; see also additional characters in: Bye, Sosa, 2013). For Ukraine $D$. wrightii (just one presumably escaped plant) was formally reported for the city of Sevastopol, Crimean Peninsula, currently occupied by the Russian Federation and thus listed by Mayorov (2018: 154) among specimens from the "territory of Russia"; two specimens collected in Belarus and Azerbaijan were also mentioned (all records were based on specimens from MW and MHA).

According to our observations (mainly in Kyiv City and Kyiv Region, but also occasionally in other regions of Ukraine), at least three related species of the group are reliably known as cultivated in Ukraine: $D$. innoxia (incl. D. meteloides), D. wrightii, and D. metel. These three species belong to the phylogenetic line (clade) corresponding to Datura L. sect. Dutra Bernh. (see Bye, Sosa, 2013; Dupin, Smith, 2018). Plants of these and some other species of Datura may persist in and near places of their cultivation and also occur (mainly as non-established casual escapes) in ruderal places and on garden waste heaps. Since all species of the genus are considered poisonous and/or hallucinogenic (see Benítez et al., 2018; Robinson et al., 2020, and references therein), control of their cultivation and naturalization is desirable.

In 2020, groups of "semi-escaped" plants of D. innoxia were observed in Kyiv near Peremohy Square at Bulvarno-Kudriavska Street, where they grew from cracks at the base of low stone walls encircling abandoned flower beds (16 October 2020; coordinates: N 50.448897, E 30.493172; Figs. 4, A-C); cultivated plants of that species have not been observed in that area, where reconstruction works were performed in 2020.

\section{Dysphania ambrosioides (L.) Mosyakin \& Clemants (Chenopodiaceae)}

Plants escaped near the place of their cultivation (in and near the New Crops Lab area) were observed in 2019 and 2020 in the M.M. Gryshko National Botanical Garden of the National Academy of Sciences of Ukraine (coordinates: N 50.417194, E 30.557558), in total several dozen plants beyond the cultivation plots. The spontaneous occurrence of that escaped species in the garden was not reported in the comprehensive checklist by Shynder (2019b). Judging from the persistence of plants during at least two years, they may become naturalized in the Kyiv area, but further observations are needed to confirm or disprove that suggestion.

\section{Erechtites hieraciifolius (L.) Raf. ex DC. (Asteraceae)}

This species (often cited as "hieraciifolia" or "hieracifolia", but see Art. 62.4 of the ICN: Turland et al., 2018), native to North America and known as naturalized and often invasive in Europe and some other parts of the world (see Belcher, 1956; Cameron, de Lange, 2002; Barkley, 2006; Darbyshire et al., 2012, etc.), is now actively spreading in western and northern regions of Ukraine (see Orlov, Yakushenko, 2011, Tretyakov et al., 2011; Tokaryuk et al., 2017; Kolomiychuk et al., 2019, and references therein), as well as in other countries of Central and Eastern Europe (e.g., Górski et al., 2003; Tretyakov et al., 2011; Bartoszek, 2019; Gudžinskas, Taura, 2020; Zaniewski et al., 2020, etc.). Its invasion in Polissya (the northern forest zone) of Ukraine and adjacent regions of Belarus seems to be especially active at present. In particular, in the Kyiv Polissya area E. hieraciifolius was recently reported from several locations in the Chornobyl (Chernobyl) Exclusion Zone (also known as the Chernobyl Nuclear Power Plant Zone of Alienation) within the Chornobyl Radiation and Ecological Biosphere Reserve in the northern part of Kyiv Region, and also in forests near Kyiv (Kolomiychuk 


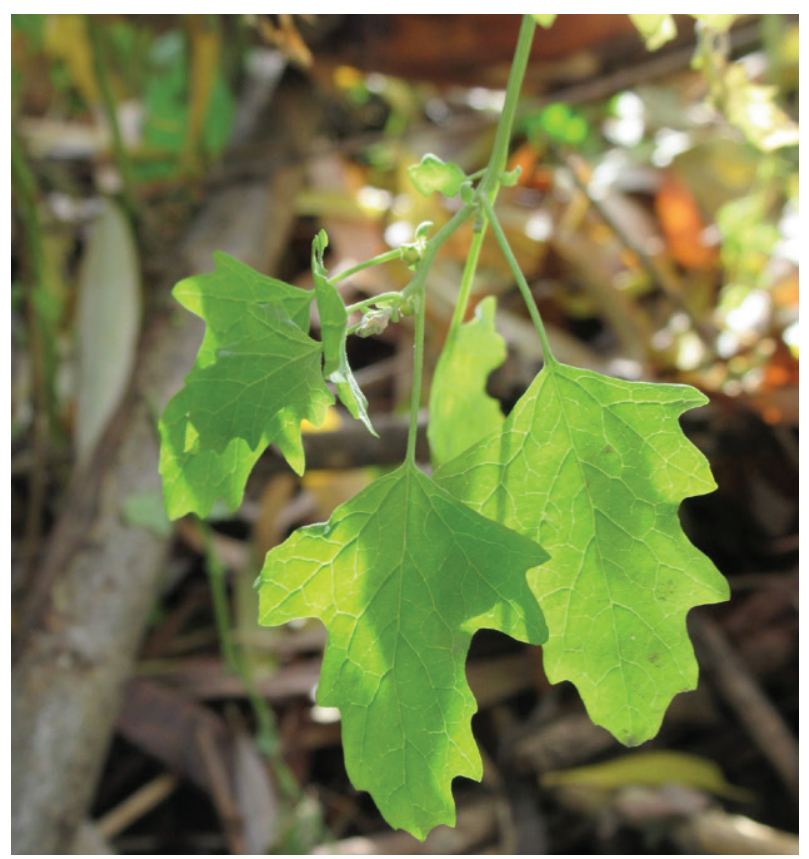

Fig. 2. Chenopodium ucrainicum, Kyiv Region, Salyvonky, 22 November 2020

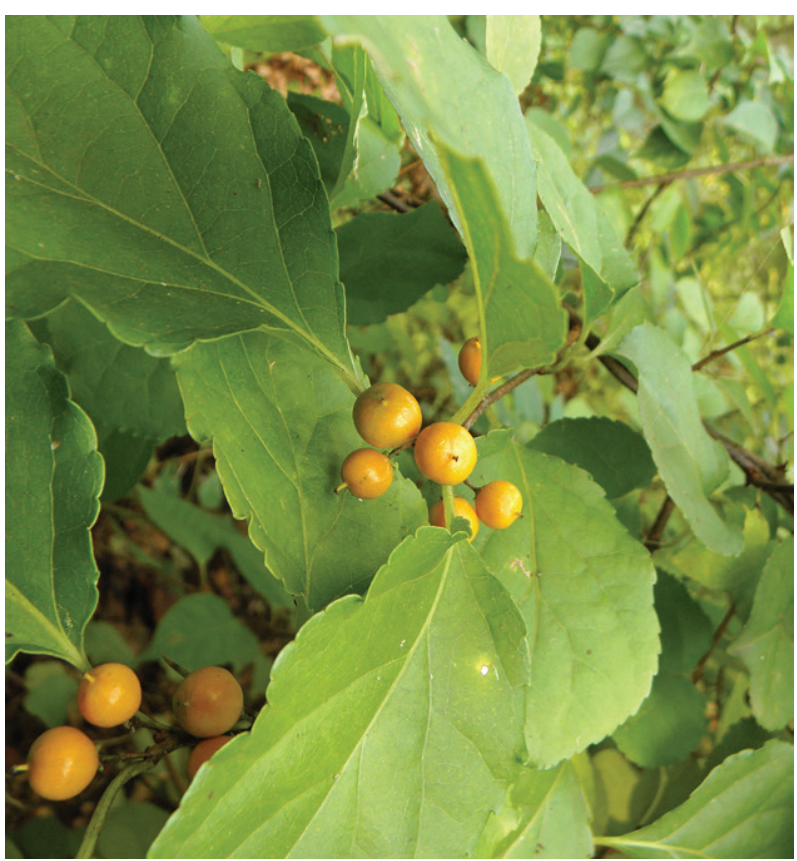

Fig. 3. Celastrus orbiculatus, Pushcha-Vodytsya Forest, 02 October 2012
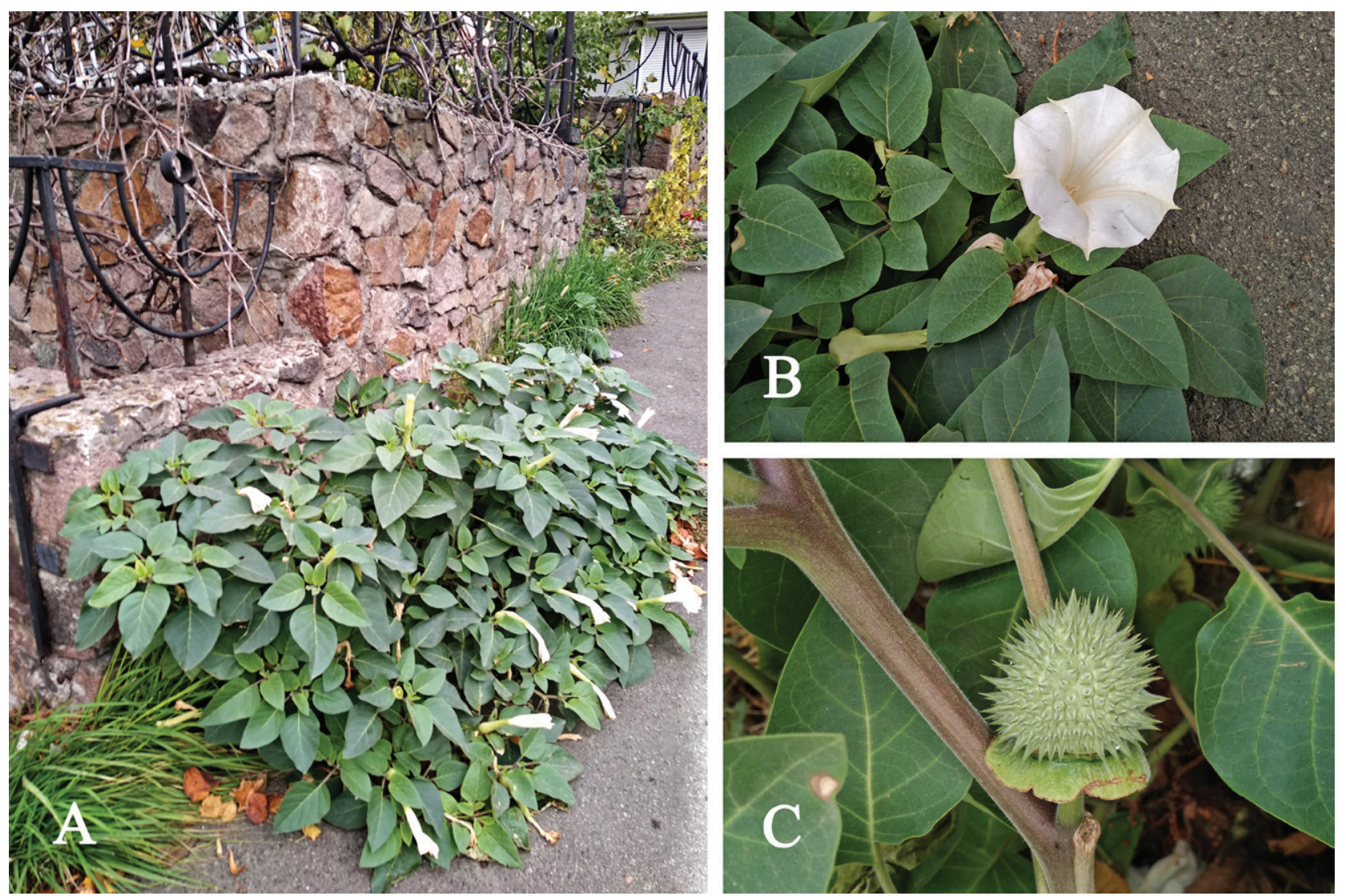

Fig. 4. Datura innoxia, Kyiv, Bulvarno-Kudriavska Street, 16 October 2020. A: plants growing along the wall; B: flower; $\mathrm{C}$ : stem pubescence and fruit 
et al., 2019). In 2020 we registered new localities and documented further spread of the species in that area.

In addition to the two localities in the Svyatoshyn Forest (within the Svyatoshyn-Bilychi branch of Holosiivskyi National Nature Park) in the western part of the city of Kyiv reported by Kolomiychuk et al. (2019), we found rather large colonies of E. hieraciifolius on 2 August 2020 within the city limits of Kyiv in the Pushcha-Vodytsya Forest, in the northwestern part of Kyiv City, north of the city tram station "Spetsdispanser" (coordinates: N 50.526238, E 30.399593, and adjacent areas in the forest compartments 103 and 104 of the Pushcha-Vodytsya Forestry; Fig. 5, B; E2, B).

However, these colonies in and near Kyiv looked dwarfed as compared to the huge stands of E. hieraciifolius observed on 12 September 2020 in pine forests near Sukholuchchya (Vyshgorod District, Kyiv Region) just south of the southern border of the Chornobyl Exclusion Zone, especially in areas affected by forest fires (thus justifying the common name American fireweed; coordinates: N 50.993231 E 30.391225; Fig. 5, A), on glades (e.g., N 50.992657, E 30.419216), and at banks of water bodies, mainly small lakes (e.g., N 50.992650, E 30.381130; Fig. E2, A). It looks like the species is already widespread in the Kyiv Polissya area (especially in pine forests and in disturbed areas) and its further invasion in the Forest and Forest-Steppe zones of Ukraine should be expected.

Mesembryanthemum ×vascosilvae (Gideon F.Sm., E.Laguna, F.Verloove \& P.P.Ferrer) Sáez \& Aymerich [= M. cordifolium L.f. $\times$ M. haeckelianum A.Berger; Aptenia $\times$ vascosilvae Gideon F.Sm., E.Laguna, F.Verloove \& P.P.Ferrer] (Aizoaceae)

The species of Aptenia N.E.Brown (Aizoaceae) usually identified as $A$. cordifolia (L.f.) Schwantes was reported as occasionally cultivated in Ukraine and other regions of Eastern Europe (Byalt, 2004, 2012). This ornamental plant is becoming increasingly popular in that part of the world, while in some countries of southern and western Europe and in regions with Mediterranean-type climates it is considered naturalized (e.g., Preston, Sell, 1988; Smith et al., 2019b). In Ukraine plants identified as $A$. cordifolia occur in open air cultivation mostly in flower beds, but occasionally they also persist in or near places of cultivation, especially in the southern regions of the country (e.g., Crimea: see Byalt, 2012: 195), and sometimes even in Kyiv (see below) when winters are mild.

It has been recently revealed that the most common and widespread cultivar known as Aptenia 'Red Apple' is not A. cordifolia s. str. but a result of hybridization between
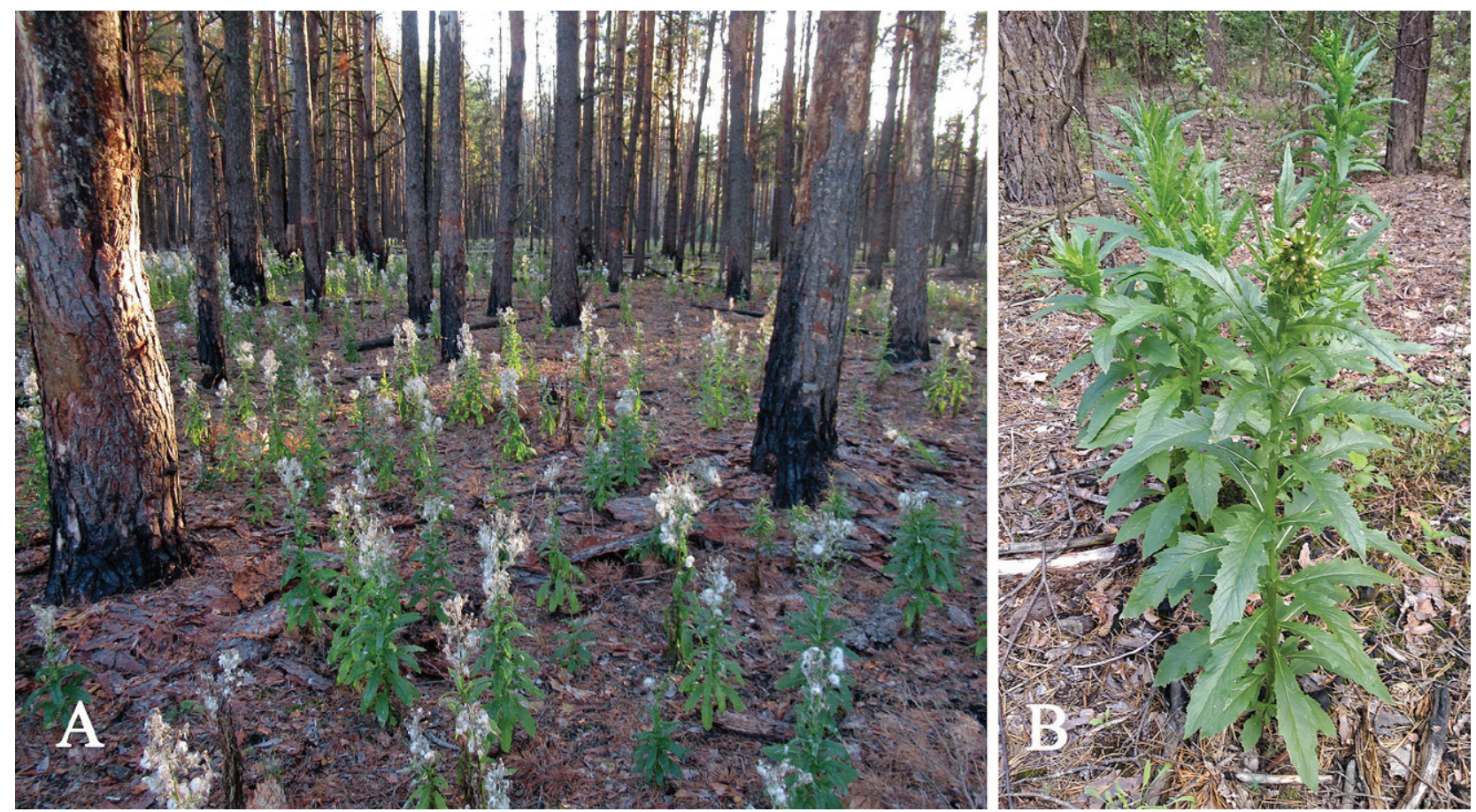

Fig. 5. Erechtites hieraciifolius. A: post-fire invasion in the pine forest, Kyiv Region, near Sukholuchchya, 12 September 2020 ; B: Pushcha-Vodytsya Forest, 2 August 2020 
A. cordifolia and A. haeckeliana (A.Berger) Bittrich ex Gerbaulet, both native to southern Africa (Smith et al., 2019a, 2019b). The name Aptenia $\times$ vascosilvae Gideon F.Sm., E.Laguna, F.Verloove \& P.P.Ferrer has been validated for that hybrid or nothospecies (Smith et al., 2020), honoring the Portuguese botanist Vasco Silva. The main characters distinguishing the hybrid and its parental species are the flower color (purple in A. cordifolia; yellowish in $A$. haeckeliana; variable in the hybrid, but mainly bright strawberry red, often yellowish in the centre) and the leaf shape (basally cordate in A. cordifolia, cuneate in A. haeckeliana, broadly cuneate or truncate in the hybrid) (see details in Smith et al., 2020).

In 2019 and 2020 it was observed by Sergei Mosyakin in open-air cultivation (mainly in flower beds and outdoor flower pots and containers) in several localities in Kyiv, but only in one place it was registered as "semi-escaped" (14 October 2019, Fig. 6) in and near an abandoned or neglected flower bed at the margin of the Syrets (Syretskyi) Park (not to be confused with the Syrets Arboretum, see below), where it most probably persisted for several years with minimal human care, or even without any human care. It would appear that most records of "A. cordifolia" for Ukraine in fact refer to this hybrid, which is here formally reported for Ukraine for the first time.

There are different opinions regarding the proper generic limits and a number of genera worth recognition in Mesembryanthemoideae; some authors, apparently being unsatisfied with intricate phylogenetic patterns revealed in the group and the lack of clear morphological characters distinguishing the traditionally recognized (and often polyphyletic or paraphyletic) genera, advocate the acceptance of only one "catch-all" monophyletic genus, Mesembryanthemum L. sensu latissimo (Klak et al., 2003, 2007, 2014; Klak, Bruyns, 2013; Hernández-Ledesma etal., 2015), while others prefer to recognize several genera re-circumscribed in accordance with (still incomplete) phylogenetic results (see Gerbaulet, 2002, 2012, 2017, and references therein). However, in the Plants of the World Online database (POWO, 2020-onward, accessed 23 November 2020 and 26 January 2021), Aptenia cordifolia (http://www.plantsoftheworldonline.org/ taxon/urn:lsid:ipni.org:names:360550-1) is considered a synonym of Mesembryanthemum cordifolium L.f. (http:// www.plantsoftheworldonline.org/taxon/urn:lsid:ipni. org:names:322566-2) and Aptenia haeckeliana (http:// www.plantsoftheworldonline.org/taxon/urn:lsid:ipni. org:names:20004144-1) is listed under the accepted name Mesembryanthemum haeckelianum A.Berger (http:// www.plantsoftheworldonline.org/taxon/urn:lsid:ipni. org:names:57619-1). Aptenia is also submerged under Mesembryanthemum s.l. in recent South African floras (Klak, 2012, 2013; Burgoyne, Bredenkamp, 2019). It is evident that many authors will follow that broad generic circumscription [e.g., as outlined in Hernández-Ledesma et al. (2015) and Klak and Bruyns (2013)], while many others, especially horticulturalists, will continue their acceptance of Aptenia and other generic segregates of Mesembryanthemum s.l.

Until recently, no name in Mesembryanthemum was available for the taxon described as Aptenia $\times$ vascosilvae, but that name was needed for followers of a wide generic concept in the group. The new combination Mesembryanthemum $\times$ vascosilvae was validated in June 2020 by Sáez and Aymerich (2020: 71; see above).

\section{Parietaria officinalis L. (Urticaceae)}

In Kyiv City the species was known as a local weed (escaped?) in the M.M Gryshko National Botanical Garden of the National Academy of Sciences of Ukraine (Shynder, 2019b; S. Mosyakin, personal observations). However, it is also known from the O.V. Fomin Botanical Garden of the Taras Shevchenko National University of Kyiv, where it was reported by Berezkina et al. (2007: 302) as occurring sporadically in various parts of the garden. At present its colonies there seem to be much larger than those known in the Gryshko Botanical Garden. The colonies of the species are mainly concentrated in the eastern part of the research sector (not open to the public, except for special guided excursions) of the Fomin Botanical Garden and along the fence separating the public and research sectors (Fig. E3, A). In some areas $P$. officinalis forms dense monodominant stands, covering the ground almost completely (Fig. 7; $\mathrm{N}$ 50.442666, E 30.503300, 13 November 2020). Expansion of that species is not mentioned in an updated checklist of the spontaneous flora of the Fomin Botanical Garden (Konaikova et al., 2015). Since that rather conspicuous species can hardly be misidentified and its large colonies can hardly be overlooked, we may assume that its dramatic expansion in the garden is a quite recent phenomenon (after 2007?).

A rather large and stable colony (observed for several years and confirmed in 2020: from 2 May until 10 and 24 November 2020) is also known along the fence in Bohdan Gavrylyshyn Street near its crossing with Marshal Rybalko Street and Mytrofan Dovnar-Zapolski Street (coordinates: N 50.455885, E 30.473312; Fig. E3, B). 
Judging from these observations, $P$. officinalis can survive winters in the Kyiv area and form there large and stable colonies, reproducing both by seeds and vegetatively by underground parts. Further spread of that species in the city and the region should be expected. Another species of the genus, Parietaria judaica L., was recently reported from the Syrets Arboretum, where it grows as a weed near greenhouses (Shynder et al., 2018).

\section{Phytolacca americana L. and other species of the genus (Phytolaccaceae)}

This species is quite often cultivated in Ukraine; it occasionally occurs as persisting or escaped near the places of cultivation. However, on 2 August 2020 we found a rather well established colony of the species in the forest of Pushcha-Vodytsya in the northwestern part of Kyiv City, quite far from any potential cultivation sites. It was although associated with a firebreak ditch plowed in the pine forest, forest compartment 104 of the Pushcha-Vodytsya Forestry (coordinates: N 50.526843, E 30.399934; Fig. 8, E4).

It should be also noted that $P$. americana was the only species of the genus mentioned in the Flora of the Ukrainian SSR (Bordzilovskyi, 1952), Ukrainian identification manuals (e.g., Prokudin et al., 1987), and the list of ergasiophytes (plants escaped from cultivation) of Ukraine (Protopopova, Shevera, 2014). However, in fact it is not the only species of the genus cultivated in Ukraine. Another species (or rather a species aggregate), known as $P$. acinosa Roxb. sensu lato (incl. P. esculenta Van Houtte $=P$. acinosa var. esculenta (Van Houtte) Tzvelev, 2004b: 103), also occurs in cultivation and can also persist in or near places of cultivation or be observed as a rare garden escape (e.g., reported by Tzvelev, 2004b, 2012). The species was reported as escaped in Western Europe (see Clement, 1998b; Verloove, 2010-onward, and references therein), and recently also from Poland (Wyrzykiewicz-Raszewska, 2009; Pliszko, Klich, 2018), Bulgaria (Zieliński et al., 2012), Croatia (Borak Martan, Šoštarić, 2016), and some other European countries. Its naturalization is possible mainly in southern parts of Ukraine and, under the present climate fluctuations, probably even in more northern areas, up north to Kyiv Region. It is considered to be a potentially invasive species even in Belarus (Dubovik, 2019).

Taxonomic patterns and species limits in the group of $P$. acinosa remain debatable. Some authors recognize several narrowly circumscribed species (e.g., Clement, 1998b), while others prefer to treat $P$. acinosa in a wide sense, noting that morphological variants in that aggregate are not well separated from each other
(Nielsen, 2001; Nienaber, Thieret, 2003; Tzvelev, 2004b, 2012; Verloove, 2010-onward, etc.). The plants of the $P$. acinosa group cultivated in Ukraine morphologically seem to be quite diverse and may belong to two or more "narrow" species; see, for example, images of plants cultivated in the Syrets Arboretum in Kyiv (Fig. E5, A) and in Kyiv Region (Fig. E5, B). Further observations on and herbarium collections of cultivated and escaped plants of Phytolacca in all regions of Ukraine are needed to reveal possible patterns and trends of their occurrence as cultivated and escaped and/or potentially naturalized species.

\section{Thladiantha dubia Bunge (Cucurbitaceae)}

This species was reported for Kyiv City as cultivated and occasionally locally escaped (e.g., Prokudin et al., 1987: 107; Mosyakin, 1989: 22-23, records of Leonid V. Mosyakin and Sergei L. Mosyakin, etc.). Recent observations revealed new localities within the city and confirmed that the species is able to form large and dense colonies (similar to those formed by other climbing species and vines, such as Echinocystis lobata (Michx.) Torr. \& A.Gray and two species of Parthenocissus Planch.) and thus should be considered as locally naturalized in our region. In particular, large colonies of $T$. dubia were revealed in ruderal habitats in the neighborhoods of Lukianivka (coordinates: N 50.457740, E 30.485364) and Kurenivka (coordinates: N 50.498783, E 30.455737), where the species sometimes forms dense stands almost completely covering trees and shrubs, fences, and the ground (e.g., Lukianivka: Fig. 9, Fig. E6). Colonies of escaped plants of T. dubia were also observed in the Syrets Arboretum by the authors in 2018-2019, and confirmed on 11 September 2020 by Sergei Mosyakin, Ganna Boiko and Valentyna Minarchenko (coordinates: N 50.481487, E 30.426060). The species has not been reported for the Syrets Arboretum in the checklist by Shynder et al. (2018).

Further spread of T. dubia to natural and semi-natural habitats of Kyiv and Kyiv Region as an invasive species should be expected. However, the dioecious nature of $T$. dubia considerably limits its spread by seeds. According to our observations, this species is represented in Kyiv localities mainly (or exclusively?) by staminate (male) plants and, consequently, it reproduces and spreads vegetatively, due to its fast-growing underground shoots and tubers. Despite that, it is considered invasive or potentially invasive in some regions of Europe (e.g., in Croatia: Alegro et al., 2010; in Ukraine: Dvirna, 2019, and references therein) and Russia (Kuluev et al., 2019; Panasenko, Anishchenko, 2020, and references therein). 


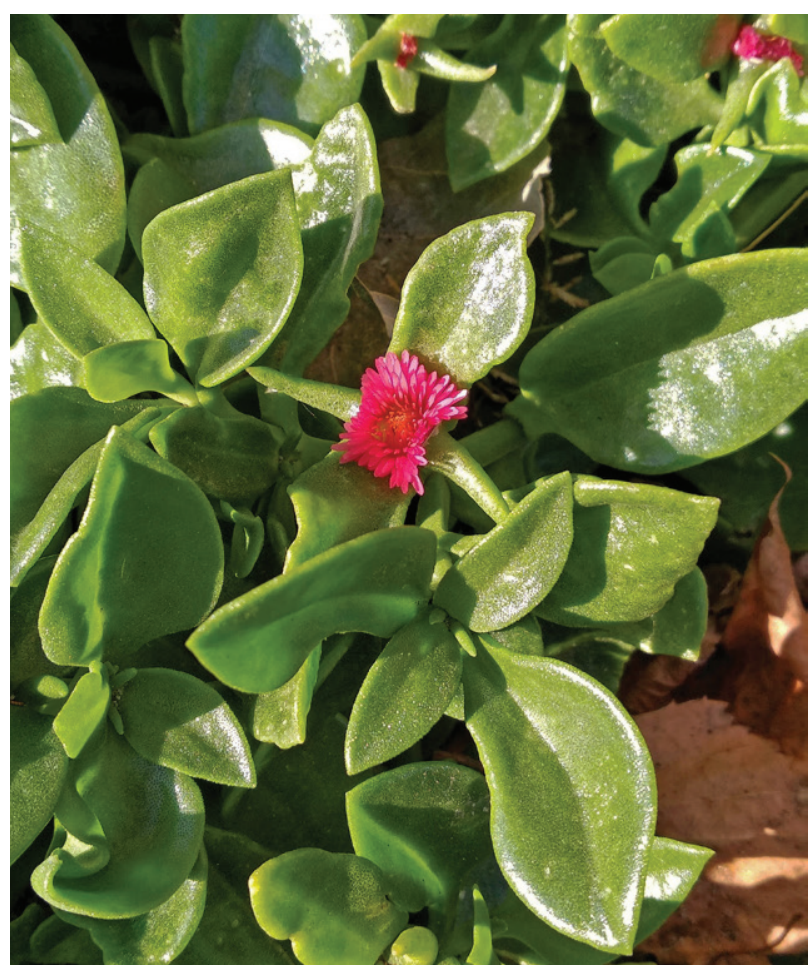

Fig. 6. Mesembryanthemum ×vascosilvae, Kyiv, Syrets Park, 14 October 2019

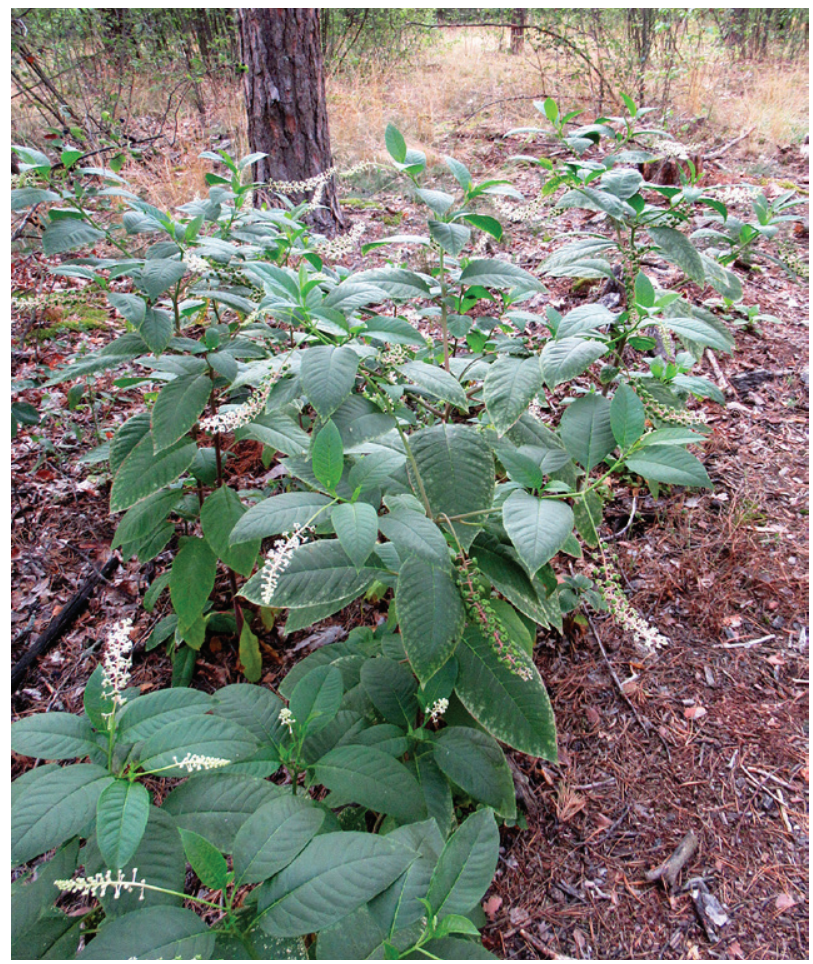

Fig. 8. Phytolacca americana, Pushcha-Vodytsya Forest, 2 August 2020

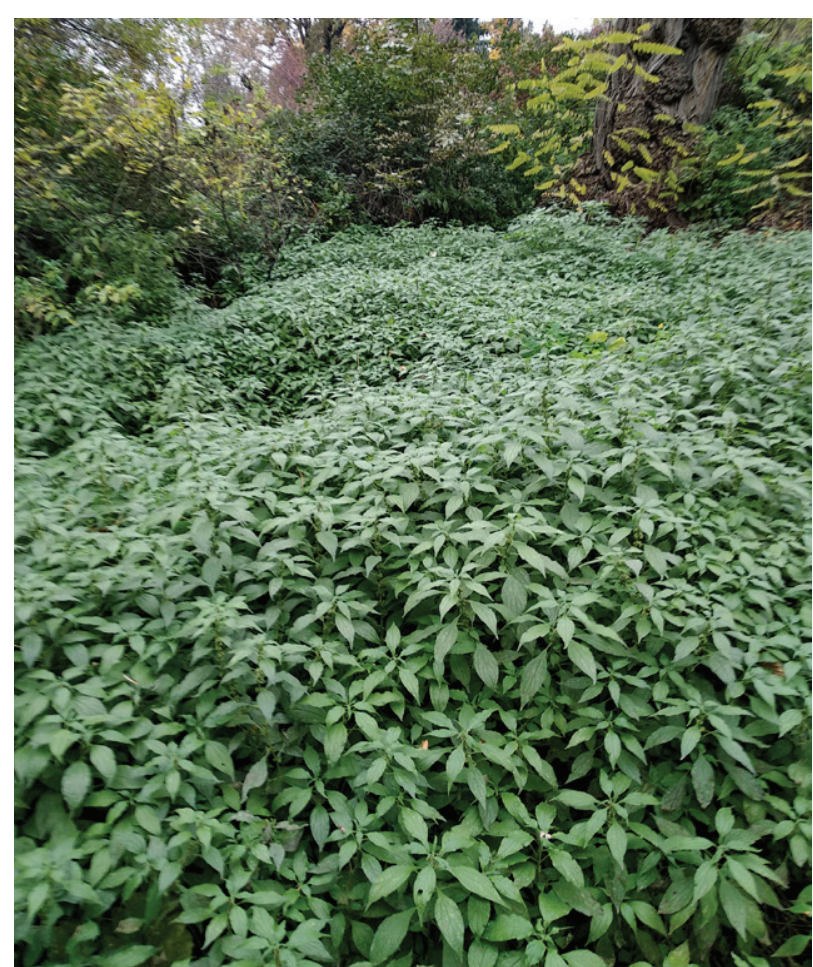

Fig. 7. Parietaria officinalis, Kyiv, Fomin Botanical Garden, 13 November 2020

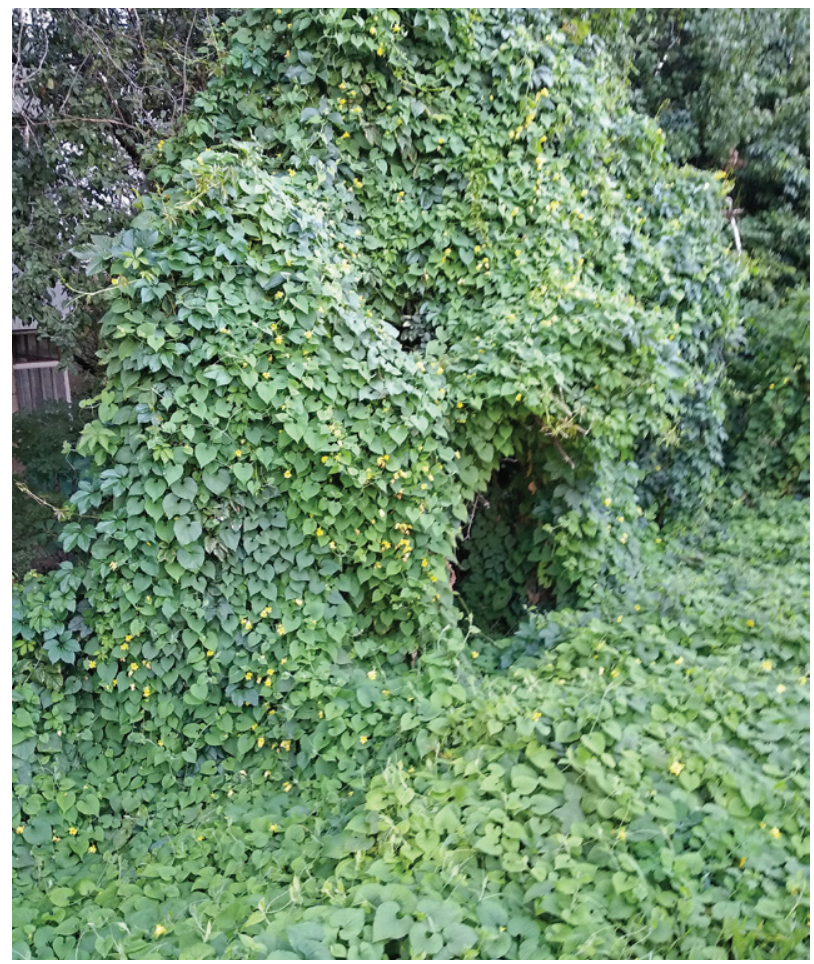

Fig. 9. Thladiantha dubia, large colony, Kyiv, Lukianivka, 8 September 2020

Ukrainian Botanical Journal, 2021, 78(2) 


\section{Concluding remarks}

The growing role of cultivated and escaped plants in the recruitment of alien floras in Europe and many other regions of the Globe is rather well documented and reviewed (e.g., Dehnen-Schmutz et al., 2007; DAISIE, 2009; Protopopova, Shevera, 2014; Pergl et al., 2016; Dullinger et al., 2017; Haeuser et al., 2018; van Kleunen et al., 2018; Vojík et al., 2020, and references therein). In accordance with that global trend, it should be noted that most of species reported above are ergasiophytes (in the wide sense of Protopopova and Shevera, 2014; Shynder, 2019a, etc.) or, in the original narrower sense of Holub and Jirásek (1967; who reserved the term "ergasiophytes" only to cultivated but not escaped plants), ergasiophygophytes (intentionally introduced casual aliens) and/or ergasiolipophytes (intentionally introduced aliens, naturalized or invasive) (see Pyšek et al., 2004; Shynder, 2019a, etc.). However, in Englishlanguage literature those terms are not widely accepted. For informal categorization of records of casual aliens in English-language publications, we think advisable to use a simple scheme proposed by Heenan et al. (2008: 258), who recognized and defined in their Casual category of alien plants in New Zealand the following four groups: Cultivation Escape ("plants that have established themselves and are regenerating only in the immediate vicinity of the cultivated parent plant/ plants"), Spontaneous Occurrence ("plants that have spontaneously established themselves well beyond the probable source of the parent plant, but are not sufficiently common to be considered naturalised"), Garden Discard ("plants that originate from the deliberate dumping of garden waste from which pieces of plant have vegetatively persisted or seed has germinated and, although persisting vegetatively, they are not spreading sexually"), and Intentional Release ("species that have been intentionally planted or had seed sown with the purpose of them becoming naturalised species").

Unfortunately, in Ukraine many researchers are reluctant to report the escape-from-cultivation cases, especially for species falling into the categories Cultivation Escape and Garden Discard. However, such cases quite often may be the first indications of an invasive potential of a cultivated species. Also, many cultivated species are taxonomically challenging, being represented by morphologically diverse forms, hybrids, cultivars, etc., as we can see from the cases of Datura, Mesembryanthemum (incl. Aptenia), and Phytolacca discussed above. Anyway, these species, even if not included in standard floras or identification manuals, should be registered in other publications and relevant online resources.

\section{Acknowledgements}

The authors are grateful to many people who facilitated our field surveys and other research. In particular, our thanks are due to (listed alphabetically): Peter J. de Lange (School of Environmental \& Animal Sciences, Unitec Institute of Technology, Auckland, Aotearoa / New Zealand), Zigmantas Gudžinskas (Nature Research Centre, Institute of Botany, Vilnius, Lithuania), Vitaliy P. Kolomiychuk (O.V. Fomin Botanical Garden of the Taras Shevchenko National University of Kyiv, Kyiv, Ukraine), and Filip Verloove (Meise Botanic Garden, Meise, Belgium), with whom we discussed various issues related to the reported plant species and who provided some important references and useful comments on the text. The KW herbarium team members Natalia M. Shiyan (Head Curator of KW), Alisa V. Shumilova and Iryna I. Diachenko (Curatorial Assistants at KW) facilitated our herbarium research and helped with preparing herbarium specimens for the National Herbarium of Ukraine (KW, M.G. Kholodny Institute of Botany, National Academy of Sciences of Ukraine, Kyiv). We are grateful to the reviewers for their useful comments and suggestions. Ganna V. Boiko and Vera P. Hayova (M.G. Kholodny Institute of Botany, National Academy of Sciences of Ukraine, Kyiv) guided the present submission through the editorial process and made several improvements in the text and images.

\section{References}

Alegro A., Bogdanović S., Rešetnik I., Boršić I. 2010. Thladiantha dubia Bunge (Cucurbitaceae), [a] new alien species in [the] Croatian flora. Natura Croatica, 19(1): 281-286.

Barclay A.S. 1959. New considerations in an old genus: Datura. Botanical Museum Leaflets, Harvard University, 18(6): 245-272. Available at: https://www.jstor. org/stable/41762193 and https://archive.org/details/ cbarchive 40559 newconsiderationsinanoldgenusd9999

Barkley T.M. 2006. Erechtites. In: Flora of North America Editorial Committee (eds.). Flora of North America North of Mexico, vol. 20. New York; Oxford: Oxford University Press, pp. 602-604.

Bartoszek W. 2019. Nowe stanowisko Erechtites hieracifolia (Asteraceae) w Karpatach polskich. Fragmenta Floristica 
et Geobotanica Polonica, 26(2): 407-411. https://doi. org/10.35535/ffgp-2019-0042

Bayón N.D. 2015. Revisión taxonómica de las especies monoicas de Amaranthus (Amaranthaceae): Amaranthus subg. Amaranthus y Amaranthus subg. Albersia. Annals of the Missouri Botanical Garden, 101(2): 261-383. http:// dx.doi.org/10.3417/2010080

Belcher R.O. 1956. A revision of the genus Erechtites (Compositae), with inquiries into Senecio and Arrhenechthites. Annals of the Missouri Botanical Garden, 43(1): 1-85. https://doi.org/10.2307/2394610

Benítez G., March-Salas M., Villa-Kamel A., ChávesJiménez U., Hernández J., Montes-Osuna N., MorenoChocano J., Cariñanos P. 2018. The genus Datura L. (Solanaceae) in Mexico and Spain - Ethnobotanical perspective at the interface of medical and illicit uses. Journal of Ethnopharmacology, 219: 133-151. https://doi. org/10.1016/j.jep.2018.03.007

Berezkina V.I., Gubar L.M., Menshova L.M., Peregrym M.M. 2007. Preliminary list of wild [spontaneous] species of vascular plants of the O.V. Fomin Botanical Garden. In: Solomakha V.A. (ed.). O.V. Fomin Botanical Garden. Index plantarum. Kyiv: Phytosociocentre, pp. 292-315. [Березкіна В.І., Губарь Л.М., Меньшова В.О., Перегрим М.M. 2007. Попередній список дикоростучих видів судинних рослин Ботанічного саду ім. акад. О.В. Фоміна. В кн.: Ботанічний сад ім. акад. О.В. Фоміна. Каталог рослин. Ред. В.А. Соломаха. Київ: Фітосоціоцентр, с. 292-315.]

Boiko G.V. 2009. New data on alien species of the genus Artemisia L. (Asteraceae) in the Ukrainian flora. Ukrainian Botanical Journal, 66(6): 833-835. [Бойко Г.В. 2009. Нові відомості щодо адвентивних видів 3 роду Artemisia L. (Asteraceae) флори України. Український ботанічний журнал, 66(6): 833-835.]

Boiko G.V., Kolomiychuk V.P. 2015. Additions to the flora of the northern coast of the Sea of Azov. Ukrainian Botanical Journal, 72(4): 340-343. [Бойко Г.В., Коломійчук В.П. 2015. Доповнення до флори північного узбережжя Азовського моря. Украӥнський ботанічний журнал, 72(4): 340-343.] https://doi.org/10.15407/ ukrbotj72.04.340

Borak Martan V., Šoštarić R. 2016. Phytolacca acinosa Roxb. (Phytolaccaceae), a new alien species in the Croatian flora. Acta Botanica Croatica, 75(2): 206-209. http:// dx.doi.org/10.1515/botcro-2016-0022

Bordzilovskyi [Bordzilowski] E.I. 1952. Phytolaccaceae. In: Kotov M.I. (ed.), Flora URSR, vol. 4. Kyiv: Academy of Sciences of the Ukrainian RSR Publ., pp. 415-417. [Бордзіловський Є.I. 1952. Phytolaccaceae. В кн.: Флора Украӥнської РСР, т. 4. Ред. М.І. Котов. Київ: Видавництво АН УРСР, с. 415-417.]

Buono S., Magrini S., Scoppola A. 2018. Datura wrightii Regel (Solanaceae), pp. 49-50. In: Galasso G., Domina G., Adorni M., Ardenghi N.M.G., Bonari G., Buono S., Cancellieri L., Chianese G., Ferretti G., Fiaschi T., Forte L., Guarino R., Labadessa R., Lastrucci L., Lazzaro L., Magrini S., Minuto L., Mossini S., Olivieri N., Scoppola A., Stinca A., Turcato C., Nepi C. Notulae to the Italian alien vascular flora: 5. Italian Botanist, 5: 45-56. https:// doi.org/10.3897/italianbotanist.5.25910

Burgoyne P.M., Bredenkamp C.L. 2019. Mesembryanthemum. In: Bredenkamp C.L. (ed.). A Flora of the Eastern Cape Province, vol. 1 [Strelitzia, vol. 41]. Pretoria: South African National Biodiversity Institute (SANBI), pp. 235-241.

Byalt V.V. 2004. Aizoaceae. In: Tzvelev N.N. (ed.). Flora Europae Orientalis, vol. 11. Moscow; St. Petersburg: KMK Scientific Press, pp. 108-113. [Бялт В.В. 2004. Aizoaceae. В кн.: Флора Восточной Европь, т. 11. Ред. Н.Н. Цвелев. Москва; Санкт-Петербург: Товарищество научных изданий КМК, с. 108-113.]

Byalt V.V. 2012. Aizoaceae. In: Tzvelev N.N., Geltman D.V. (eds.). Conspectus Florae Europae Orientalis, vol. 1. St. Petersburg; Moscow: KMK Scientific Press, pp. 194196. [Бялт В.В. 2012. Aizoaceae. В кн.: Конспект флоры Восточной Eвропьл, т. 1. Ред. Н.Н. Цвелев, Д.В. Гельтман. Санкт-Петербург; Москва: Товарищество научных изданий КМК, с. 194-196.]

Bye R., Sosa V. 2013. Molecular phylogeny of the jimsonweed genus Datura (Solanaceae). Systematic Botany, 38(3): 818-829. https://doi.org/10.1600/036364413X670278

Cameron E.K., de Lange P.J. 2002. American fireweed (Erechtites hieraciifolia) moves north. Auckland Botanical Society Journal 57(2): 102-103. Available at: $\quad$ https://bts.nzpcn.org.nz/site/assets/files/20557/ auck 2002 57_2 102-103.pdf

Clement E.J. 1998a. Datura. In: Rich T.C.G., Jermy A.C. (eds.), Plant Crib 1998. London: Botanical Society of the British Isles. Available at: https://bsbi.org/wp-content/ uploads/dlm uploads/Datura_Crib_3.pdf (Accessed 15 February 2021).

Clement E.J. 1998b. Phytolacca. In: Rich T.C.G., Jermy A.C. (eds.), Plant Crib 1998. London: Botanical Society of the British Isles. Available at: https://bsbi.org/wp-content/ uploads/dlm uploads/Phytolacca_Crib.pdf (Accessed 15 February 2021).

DAISIE. 2009. Handbook of alien species in Europe [Invading Nature - Springer Series in Invasion Ecology, vol. 3]. Dordrecht: Springer Netherlands [electronic edition: Springer Science + Business Media B.V.], xxviii + 399 pp. https://doi.org/10.1007/978-1-4020-8280-1

Darbyshire S.J., Francis, A., DiTommaso A., Clements D.R. 2012. The biology of Canadian weeds. 150 Erechtites hieraciifolius (L.) Raf. ex DC. Canadian Journal of Plant Science, 92(4): 729-746. https://doi.org/10.4141/ cjps2012-003

Dehnen-Schmutz K., Touza J., Perrings C., Williamson M. 2007. A century of the ornamental plant trade and its impact oninvasion success. Diversityand Distributions, 13(5):527534. https://doi.org/10.1111/j.1472-4642.2007.00359.x

Dubovik D.V. 2019. Potentially invasive plant species in the flora of Belarus. In: Materials of the International Scientific Conference "Flora and Vegetation in a Changing World: Problems of Studying, Preserving and Rational Use". Minsk: Kolorgrad, pp. 196-202. [Дубовик Д.В. 2019. Потенциально инвазионные виды растений во флоре Беларуси. В сб.: Флора и растительность в 
меняюшемся мире: проблемы изучения, сохранения u рационального использования. Материаль Международной научной конференции (Минск, 24-27 сентября 2019 года). Минск: Колорград, с. 196-202].

Dullinger I., Wessely J., Bossdorf O., Dawson W., Essl F., Gattringer A., Klonner G., Kreft H., Kuttner M., Moser D., Pergl J., Pyšek P., Thuiller W., van Kleunen M., Weigelt P., Winter M., Dullinger S. 2017. Climate change will increase the naturalization risk from garden plants in Europe. Global Ecology and Biogeography, 26(1): 43-53. https://doi.org/10.1111/geb.12512

Dupin J., Smith S.D. 2018. Phylogenetics of Datureae (Solanaceae), including description of the new genus Trompettia and re-circumscription of the tribe. Taxon, 67(2): 359-375. https://doi.org/10.12705/672.6

Dvirna T.S. 2019. Ergasiophytes of the alien fraction of the flora of Romensko-Poltavsky Geobotanical District (Ukraine): checklist and analysis. Geo\&Bio (Kyiv), 18: 2136. [Двірна Т.С. 2019. Ергазіофіти адвентивної фракції флори Роменсько-Полтавського геоботанічного округу (Україна): конспект та аналіз. Geo\&Bio (Киї), 18: 2136.] https://doi.org/10.15407/gb1804

El Mokni R. 2019. Datura wrightii Regel, pp. 107-108. In: von Raab-Straube E., Raus Th. (eds.). Euro+Med-Checklist Notulae, 10 [Notulae ad floram euro-mediterraneam pertinentes No. 39]. Willdenowia, 49(1): 95-115. https:// doi.org/10.3372/wi.49.49111

Geeta R., Gharaibeh W. 2007. Historical evidence for a preColumbian presence of Datura in the Old World and implications for a first millennium transfer from the New World. Journal of Biosciences, 32 (Supplement issue 3): 1227-1244. https://doi.org/10.1007/s12038-007-0132-y

Gerbaulet M. 2002. Aptenia: Mesembryanthemoideae. In: Hartmann H.E.K. (ed.). Illustrated handbook of succulent plants: Aizoaceae A-E. Berlin; Heidelberg: Springer, pp. 66-68. https://doi.org/10.1007/978-3-642-56306-5 2

Gerbaulet M. 2012. One or many genera in Mesembryanthemoideae (Aizoaceae)? Discussion of a conflict in genus perception. Bradleya, 30: 187-198. https://doi.org/10.25223/brad.n30.2012.a23

Gerbaulet M. 2017. Aptenia: Mesembryanthemoideae. In: Hartmann H.E.K. (ed.). Illustrated handbook of succulent plants: Aizoaceae. Ed. 2. Berlin; Heidelberg: Springer, pp. 117-122. https://doi. org/10.1007/978-3-662-49260-4 12

Górski P., Czarna A., Tokarska-Guzik B. 2003. Distribution of Erechtites hieracifolia (L.) Raf. ex DC. (Asteraceae) in Poland. In: Zając A., Zając M., Zemanek B. (eds.). Phytogeographical problems of synanthropic plants. Cracow: Institute of Botany, Jagiellonian University, pp. 147-153.

Gudžinskas Z. 2017. Alien herbaceous plant species new to Lithuania. Botanica Lithuanica, 23(1): 33-42. https://doi. org/10.1515/botlit-2017-0003

Gudžinskas Z., Petrulaitis L., Žalneravičius E. 2017. New woody alien plant species recorded in Lithuania. Botanica Lithuanica, 23(2): 153-168. https://doi.org/10.1515/ $\underline{\text { botlit-2017-0017 }}$
Gudžinskas Z., Petrulaitis L., Žalneravičius E. 2020. Emerging invasion threat of the liana Celastrus orbiculatus (Celastraceae) in Europe. NeoBiota, 56: 1-25. https://doi. org/10.3897/neobiota.56.34261

Gudžinskas Z., Taura L. 2020. New alien plant species recorded in South Lithuania. Botanica (Vilnius), 26(2): 170-183. https://doi.org/10.2478/botlit-2020-0018

Haegi L. 1976. Taxonomic account of Datura L. in Australia with a note on Brugmansia Pers. Australian Journal of Botany, 24(3): 415-435. https://doi.org/10.1071/ BT9760415

Haeuser E., Block S., Dawson W., Thuiller W., Dullinger S., Bossdorf O., Carboni M., Conti L., Moser D., Winter M., Klonner G., Weigelt P., Münkemüller T., Parepa M., Talluto M.V. 2018. European ornamental garden flora as an invasion debt under climate change. Journal of Applied Ecology, 55(5): 2386-2395. https://doi. org/10.1111/1365-2664.13197

Heenan P.B., de Lange P.J., Cameron E.K., Parris B.S. 2008. Checklist of dicotyledons, gymnosperms, and pteridophytes naturalised or casual in New Zealand: additional records 2004-06. New Zealand Journal of Botany, 46(2): 257-283. https://doi. org/10.1080/00288250809509765

Hernández-Ledesma P., Berendsohn W.G., Borsch T., von Mering S., Akhani H., Arias S., Castañeda-Noa I., Eggli U., Eriksson R., Flores-Olvera H., Fuentes-Bazán S., Kadereit G., Klak C., Korotkova N., Nyffeler R., Ocampo G., Ochoterena H., Oxelman B., Rabeler R.K., Sanchez A., Schlumpberger B.O., Uotila P. 2015. A taxonomic backbone for the global synthesis of species diversity in the angiosperm order Caryophyllales. Willdenowia, 45(3): 281-383. https://doi.org/10.3372/wi.45.45301

Holub J., Jirásek V. 1967. Zur Vereinheitlichung der Terminologie in der Phytogeographie. Folia Geobotanica et Phytotaxonomica, 2: 69-113. https://doi.org/10.1007/ BF02851755

Klak C. 2012. Mesembryanthemum. In: Manning J., Goldblatt P. (eds.). Plants of the Greater Cape Floristic Region, vol. 1: The Core Cape Flora [Strelitzia, vol. 29]. Pretoria: South African National Biodiversity Institute (SANBI), pp. 293-296.

Klak C. 2013. Mesembryanthemum. In: Snijman D.A. (ed.). Plants of the Greater Cape Floristic Region, vol. 2: The Extra Cape Flora [Strelitzia, vol. 30]. Pretoria: South African National Biodiversity Institute (SANBI), pp. 208-217.

Klak C., Bruyns P.V. 2013. A new infrageneric classification for Mesembryanthemum (Aizoaceae: Mesembryanthemoideae). Bothalia, 43(2): 197-206. https://doi.org/10.4102/abc.v43i2.95

Klak C., Bruyns P.V., Hedderson T.A. 2007. A phylogeny and new classification for Mesembryanthemoideae (Aizoaceae). Taxon, 56(3): 737-756. https://doi.org/10.2307/25065857

Klak C., Hanáček P., Bruyns P.V. 2014. Phylogeny and taxonomy for Mesembryanthemum subg. Volkeranthus (Aizoaceae - Mesembryanthemoideae). South African Journal of Botany, 95: 112-122. http://dx.doi. org/10.1016/j.sajb.2014.08.006 
Klak C., Khunou A., Reeves G., Hedderson T. 2003. A phylogenetic hypothesis for the Aizoaceae (Caryophyllales) based on four plastid DNA regions. American Journal of Botany, 90(10): 1433-1445. http:// dx.doi.org/10.3732/ajb.90.10.1433

Kolomiychuk V., Shevera M., Vorobyov E., Orlov O., Pryadko O. 2019. Erechtites hieraciifolia (L.) Raf. ex DC. (Asteraceae Bercht. \& J.Presl), new for the Kyiv Polissia alien species. Visnyk of the Taras Shevchenko National University of Kyiv. Biology, 3(79): 37-43. [Коломійчук В., Шевера М., Воробйов С., Орлов О., Прядко О. 2019. Erechtites hieraciifolia (L.) Raf. ex DC. (Asteraceae Bercht. \& J.Presl) - новий вид адвентивних рослин для флори Київського Полісся. Вісник Київського начіонального університету імені Тараса Шевченка. Біологія, 3(79): 37-43.]

Konaikova V.O., Peregrym M.M., Gubar L.M. 2015. Additions to a list of [the] spontaneous flora of O.V. Fomin Botanical Garden of [the] Taras Shevchenko National University of Kyiv. Studia Biologica (Kyiv), 9(2): 159-168. [Конайкова В.О., Перегрим М.М., Губарь Л.М. 2015. Доповнення до списку спонтанної флори Ботанічного саду імені академіка О.В. Фоміна Київського національного університету імені Тараса Шевченка. Біологічні Студї̈, 9(2): 159-168.]

Kondratyuk E.M., Burda R.I., Ostapko V.M., Kuskov A.E., Gumech V.S., Grynevska O.G. 1987. Supplements to the "Synopsis of the flora of the South-East of Ukraine". Ukrainian Botanical Journal, 43(3): 2327. ГКондратюк Є.M., Бурда P.I., Остапко B.M., Кусков А.С., Гумеч В.С., Гриневська О.Г. 1987. Доповнення до "Конспекту флори південного сходу України". Український ботанічний журнал, 43(3): 23-27.]

Kuluev B.R., Shvets D.Y., Golovanov Y.M., Probatova N.S. 2019. Thladiantha dubia (Cucurbitaceae) in the Republic of Bashkortostan as a dangerous weed with high invasive potential. Russian Journal of Biological Invasions, 10(2): 160-170. https://doi.org/10.1134/S2075111719020097

Lakušić D., Rat M., Anačkov G., Jovanović S. 2017. Datura inoxia Mill. (Solanaceae), a new alien species in Serbia. Biologica Nyssana, 8(1): 47-51.

Leicht-Young S.A., Pavlovic N.B., Grundel R., Frohnapple K.J. 2007. Distinguishing native (Celastrus scandens L.) and invasive ( $C$. orbiculatus Thunb.) bittersweet species using morphological characteristics. Journal of the Torrey Botanical Society, 134(4): 441-450.

Luna Cavazos M., Jiao M., Bye R. 2000. Phenetic analysis of Datura section Dutra (Solanaceae) in Mexico. Botanical Journal of the Linnean Society, 133(4): 493-507. https:// doi.org/10.1006/bojl.2000.0337

Maslo S., Šarić Š. 2019. Datura innoxia Mill. (Solanaceae), a new alien species in the flora of Bosnia and Herzegovina. Thaiszia - Journal of Botany, 29(2): 225-230. https://doi. org/10.33542/TJB2019-2-07

Mayorov S.R. 2018. Datura wrightii Regel (Solanaceae) - a new alien species for the flora of Russia. Transactions of the Karelian Research Centre of the Russian Academy of Sciences. Biogeography, 8: 154-155. [Майоров C.P. 2018. Datura wrightii Regel (Solanaceae) - новый чужеродный вид для флоры России. Труды Карельского научного иентра РАН. Биогеография, 8: 154-155.] http://dx.doi. org/10.17076/bg730

Mosyakin S.L. 1989. Floristic finds in the city of Kiev and its environs. Ukrainian Botanical Journal, 46(4): 21-23. [Мосякін С.Л. 1989. Флористичні знахідки в м. Києві та на його околицях. Український ботанічний журнал, 46(4): 21-23.]

Mosyakin S.L. 1990. New and noteworthy alien species of Artemisia L. (Asteraceae) in the Ukrainian SSR. Ukrainian Botanical Journal, 47(4): 10-13.

Mosyakin S.L. 1991. Preliminary list of recent additions to the alien flora of Ukraine. Ukrainian Botanical Journal, 48(4): $28-34$.

Mosyakin S.L. 1992. Floristic notes on alien plants in Kiev. Ukrainian Botanical Journal, 49(6): 36-39. [Мосякін С.Л. 1992. Флористичні нотатки про адвентивні рослини м. Києва. Украйнський ботанічний журнал, 49(6): 36-39.]

Mosyakin S.L. 1995a. The genus Amaranthus L. (Amaranthaceae) in Ukraine: an overview. Ukrainian Botanical Journal, 52(2): 225-234. [Мосякін С.Л. 1995а. Огляд роду Amaranthus L. (Amaranthaceae) в Україні. Украӥнський ботанічний журнал, 52(2): 225-234.]

Mosyakin S.L. 1995b. Additional data on distribution of some species of Amaranthus L. (Amaranthaceae) in Ukraine. Ukrainian Botanical Journal, 52(3): 384387. [Мосякін С.Л. 1995b. Додаткові відомості про поширення деяких видів роду Amaranthus L. (Amaranthaceae) в Україні. Украӥнський ботанічний журнал, 52(3): 384-387.]

Mosyakin S.L. 1996. Amaranthus. In: Tzvelev N.N. (ed.). Flora Europae Orientalis, vol. 9. St. Petersburg: Mir i Sem'ya-95, pp. 11-18. [Мосякин С.Л. 1996. Amaranthus. В кн.: Флора Восточной Европьл, т. 9. Ред. Н.Н. Цвелев. Санкт-Петербург: Мир и семья-95, с. 11-18.]

Mosyakin S.L., Fedoronchuk M.M. 1999. Vascular plants of Ukraine. A nomenclatural checklist. Kiev: M.G. Kholodny Institute of Botany, NAS of Ukraine, xxiv $+346 \mathrm{pp}$.

Mosyakin S.L., Mandák B. 2020. Chenopodium ucrainicum (Chenopodiaceae / Amaranthaceae sensu APG), a new diploid species: a morphological description and pictorial guide. Ukrainian Botanical Journal, 77(4): 237-248. https://doi.org/10.15407/ukrbotj77.04.237

Mosyakin S.L., Robertson K.R. 1996. New infrageneric taxa and combinations in Amaranthus (Amaranthaceae). Annales Botanici Fennici, 33(4): 275-281. Available at: https://www.jstor.org/stable/23726306

Mosyakin S.L., Robertson K.R. 2003. Amaranthus. In: Flora of North America Editorial Committee (eds.). Flora of North America North of Mexico, vol. 4. New York; Oxford: Oxford University Press, pp. 410-435.

Nielsen H. 2001. Phytolaccaceae. In: Jonsell B. (ed.). Flora Nordica, vol. 2. Stockholm: Bergius Foundation, Royal Swedish Academy of Sciences, pp. 73-74.

Nienaber M.A., Thieret J.W. 2003. Phytolaccaceae. In: Flora of North America Editorial Committee (eds.). Flora of North America North of Mexico, vol. 4. New York; Oxford: Oxford University Press, pp. 3-11. 
Orlov O.O., Yakushenko D.M. 2011. Distribution and ecocoenological peculiarities of Erechtites hieracifolia (L.) Raf. ex DC. (Asteraceae) in Ukraine. Ukrainian Botanical Journal, 68(6): 795-804. [Орлов О.О., Якушенко Д.М. 2011. Поширення та еколого-ценотичні особливості Erechtites hieracifolia (L.) Raf. ex DC. (Asteraceae) в Україні. Украӥнський ботанічний журнал, 68(6): 795-804.]

Panasenko N.N., Anishchenko L.N. 2020. Thladiantha dubia Bunge in Bryansk Region: distribution, ecology, and biochemical characteristics. Russian Journal of Biological Invasions, 11(3): 268-276. https://doi.org/10.1134/ $\underline{\mathrm{S} 2075111720030091}$

Pavlovic N.B., Young S.L., Grundel R., Frohnapple K.J. 2007. American and Oriental Bittersweet Identification. GLSC Fact Sheet 2007-2. Ann Arbor, Michigan: U.S. Department of the Interior: U.S. Geological Survey, Great Lakes Science Center, 2 pp. Available at: https://www.fs.usda. gov/Internet/FSE_DOCUMENTS/fsbdev3 017307.pdf

Pergl J., Sádlo J., Petř́k P., Danihelka J., Chrtek J., Hejda M., Moravcová L., Perglová I., Štajerová K., Pyšek P. 2016. Dark side of the fence: ornamental plants as a source of wild-growing flora in the Czech Republic. Preslia, 88(2): 163-184.

Pliszko A., Klich S. 2018. A new record of Phytolacca acinosa (Phytolaccaceae) in Poland. Acta Musei Silesiae Scientiae Naturales, 67: 181-183. https://doi.org/10.2478/ cszma-2018-0013

Pooler M.R., Dix R.L., Feely J. 2002. Interspecific hybridizations between the native bittersweet, Celastrus scandens, and the introduced invasive species, C. orbiculatus. Southeastern Naturalist, 1(1): 69-76.

POWO. 2020-onward. Plants of the World Online. Facilitated by the Royal Botanic Gardens, Kew. Available at: http:// www.plantsoftheworldonline.org (Accessed 20 August 2020 and 15 February 2021).

Preston C.D., Sell P.D. 1988. The Aizoaceae naturalized in the British Isles. Watsonia, 17: 217-245.

Prokudin Yu.N. (ed.) et al. 1987. Identification manual of higher [vascular] plants of Ukraine. Kiev [Kyiv]: Naukova Dumka, 548 pp. [Определитель высших растений Украины. 1987. Отв. ред. Ю.Н. Прокудин и др. Киев: Наукова думка, 548 с.]

Protopopova V.V., Shevera M.V. 2014. Ergasiophytes of the Ukrainian flora. Biodiversity: Research and Conservation, 35(1): 31-46. https://doi.org/10.2478/biorc-2014-0018

Pyšek P., Richardson D.M., Rejmánek M., Webster G.L., Williamson M., Kirschner J. 2004. Alien plants in checklists and floras: towards better communication between taxonomists and ecologists. Taxon, 53(1): 131143. https://doi.org/10.2307/4135498

Robinson D.W., Brown K., McMenemy M., Dennany L., Baker M.J., Allan P., Cartwright C., Bernard J., Sturt F., Kotoula E., Jazwa C., Gill K.M., Randolph-Quinney P., Ash T., Bedford C., Gandy D., Armstrong M., Miles J., Haviland D. 2020. Datura quids at Pinwheel Cave, California, provide unambiguous confirmation of the ingestion of hallucinogens at a rock art site. Proceedings of the National Academy of Sciences (USA), 117(49): 3102631037. https://doi.org/10.1073/pnas.2014529117
Sáez L., Aymerich P. 2020. A new nomenclatural combination in Mesembryanthemum L. (Mesembryanthemoideae, Aizoaceae). Butlletí de la Institució Catalana d'Història Natural, 84: 71. Available at: https://ichn2.iec.cat/pdf/ Butlleti 84 2020/09 2020 Saez \& Aymerich.pdf

Sáez L., Bibiloni G., Rita J., Gil L., Moragues E., Romero Zarco C., Vicens J. 2015. Additions and amendments to the flora of the Balearic Islands. Orsis, 29: 173-192.

Shynder O.I. 2019a. Spontaneous flora of [the] M.M. Gryshko National Botanical Garden of the NAS of Ukraine (Kyiv). 2. Methodological problems and criteria for selection of escaped plants in botanical garden conditions. Plant Introduction, [vol. of 2019] No. 2: 3-16. [Шиндер O.I. 2019a. Спонтанна флора Національного ботанічного саду імені М.М. Гришка НАН України (м. Київ). Повідомлення 2. Методологічні проблеми і критерії виділення адвентивних ергазіофітів в умовах інтродукційного осередку. Інтродукиія рослин, №2: 3-16.] https://doi.org/10.5281/zenodo.3240995

Shynder O.I. 2019b. Spontaneous flora of [the] M.M. Gryshko National Botanical Garden of the NAS of Ukraine (Kyiv). 3. Escaped plants. Plant Introduction, [vol. of 2019] 3: 14-29. [Шиндер O.I. 2019. Спонтанна флора Національного ботанічного саду імені М.М. Гришка НАН України (м. Київ). Повідомлення 3. Адвентивні види: ергазіофіти. Інтродукиія рослин, 3: 14-29.] https://doi.org/10.5281/zenodo.3404102

Shynder O.I., Glukhova S.A., Mykhaylyk S.M. 2018. Spontaneous flora of the Syrets Arboretum (Kyiv). Introduktsiya Roslyn, [vol. of 2018] No. 2: 54-64. [Шиндер O.I., Глухова C.А., Михайлик С.M. 2018. Спонтанна флора Сирецького дендрологічного парку загальнодержавного значення (м. Київ). Інтродукиія рослин, №2: 54-64.]

Smith G.F., Silva V., Figueiredo E. 2019a. Aptenia 'Red Apple' (Aizoaceae / Mesembryanthemaceae), a common cultivar derived from a hybrid between two Aptenia species endemic to southern Africa. Bradleya, 37: 179183. https://doi.org/10.25223/brad.n37.2019.a15

Smith G.F., Silva V., Figueiredo E. 2019b. Representatives of Aptenia N.E.Br. (Aizoaceae / Mesembryanthemaceae), an endemic southern African genus, naturalised in Portugal. Bradleya, 37: 184-190. https://doi.org/10.25223/brad. n37.2019.a16

Smith G.F., Laguna E., Verloove F., Ferrer-Gallego P.P. 2020. Aptenia $\times$ vascosilvae $(A$. cordifolia $\times A$. haeckeliana) (Aizoaceae), the new nothospecies from which the horticulturally popular cultivar Aptenia 'Red Apple' was derived. Phytotaxa, 441(2): 221-224. https://doi. org/10.11646/phytotaxa.441.2.10

Symon D., Haegi L.A.R. 1991. Datura (Solanaceae) is a New World genus. In: Hawkes J.G., Lester R.N., Nee M., Estrada N. (eds.). Solanaceae III: taxonomy, chemistry, evolution. London: Academic Press, pp. 197-210.

Thiers B. 2008-onward. Index Herbariorum. A global directory of public herbaria and associated staff. New York Botanical Garden's Virtual Herbarium. Available from: http://sweetgum.nybg.org/science/ih. Accessed 15 February 2021. 
Tokaryuk A.I., Chorney I.I., Budzhak V.V. 2017. Erechtites hieracifolia (L.) Raf. ex DC. (Asteraceae) in meadow complexes of Pocuttya. Biological Systems, 9(1): 144146. [Токарюк A.I., Чорней I.I., Буджак В.В. 2017. Erechtites hieracifolia (L.) Raf. ex DC. (Asteraceae) y лучних комплексах Покуття. Біологічні системи, 9(1): 144-146.]

Tretyakov D.I., Dubovik D.I., Orlov A.A., Iakushenko D.N. 2011. Erechtites hieraciifolius (L.) Raf. ex DC. (Asteraceae) in Belarus and Ukraine. Botanika (Minsk), 40: 138-147. [Третьяков Д.И., Дубовик Д.В., Орлов А.А., Якушенко Д.Н. 2011. Erechtites hieraciifolius (L.) Raf. ex DC. (Asteraceae) в Полесье Беларуси и Украины. Ботаника (исследования) (Минск), 40: 138-147].

Turland N.J., Wiersema J.H., Barrie F.R., Greuter W., Hawksworth D.L., Herendeen P.S., Knapp S., Kusber W.-H., Li D.-Z., Marhold K., May T.W., McNeill J., Monro A.M., Prado J., Price M.J., Smith G.F. 2018. International Code of Nomenclature for algae, fungi, and plants (Shenzhen Code) adopted by the Nineteenth International Botanical Congress, Shenzhen, China, July 2017 [Regnum Vegetabile, vol. 159]. Glashütten: Koeltz Botanical Books, xxxviii + 254 pp. https://doi. org/10.12705/Code.2018

Tyshchenko O.V., Tyshchenko V.M., Kucheryava L.F. 2013. A new record of Celastrus scandens L. (Celastraceae) at [the] protected area Rizanyi Yar (Cherkasy Region). Ukrainian Botanical Journal, 70(5): 646-648. [Тищенко О.В., Тищенко В.М., Кучерява Л.Ф. 2013. Знахідка Celastrus scandens L. (Celastraceae) в заповідному урочищі Різаний Яр (Черкаська обл.). Український ботанічний журнал, 70(5): 646-648.]

Tzvelev N.N. 2004a. Celastraceae. In: Tzvelev N.N. (ed.). Flora Europae Orientalis, vol. 11. Moscow; St. Petersburg: KMK Scientific Press, pp. 437-449. [Цвелев Н.Н. 2004a. Celastraceae. В кн.: Флора Восточной Европь, т. 11. Ред. Н.Н. Цвелев. Москва; Санкт-Петербург: Товарищество научных изданий КМК, с. 437-449.]

Tzvelev N.N. 2004b. Phytolaccaceae. In: Tzvelev N.N. (ed.). Flora Europae Orientalis, vol. 11. Moscow; St. Petersburg: KMK Scientific Press, pp. 102-103. [Цвелев Н.Н. 2004. Phytolaccaceae. В кн.: Флора Восточной Eвропь, т. 11. Ред. Н.Н. Цвелев. Москва; Санкт-Петербург: Товарищество научных изданий КМК, с. 102-103.]

Tzvelev N.N. 2012. Phytolaccaceae. In: Tzvelev N.N., Geltman D.V. (eds.). Conspectus Florae Europae Orientalis, vol. 1. St. Petersburg; Moscow: KMK Scientific Press, pp. 192-193. [Цвелев Н.Н. 2012. Phytolaccaceae. В кн.: Конспект флоры Восточной Европь, т. 1. Ред. Н.Н. Цвелев, Д.В. Гельтман. Санкт-Петербург; Москва: Товарищество научных изданий КМК, с. 192-193.]

van Kleunen M., Essl F., Pergl J., Brundu G., Carboni M., Dullinger S., Early R., González-Moreno P., Groom Q.J., Hulme P.E., Kueffer C., Kühn I., Máguas C., Maurel N., Novoa A., Parepa M., Pyšek P., Seebens H., Tanner R., Touza J., Verbrugge L., Weber E., Dawson W., Kreft H., Weigelt P., Winter M., Klonner G., Talluto M.V., DehnenSchmutz K. 2018. The changing role of ornamental horticulture in alien plant invasions. Biological Reviews, 93(3): 1421-1437. https://doi.org/10.1111/brv.12402
Verloove F. 2006. Catalogue of neophytes in Belgium (18002005). Scripta Botanica Belgica, 39: 1-89.

Verloove F. 2008. Datura wrightii (Solanaceae), a neglected xenophyte, new to Spain. Bouteloua, 4: 37-40.

Verloove F. 2010-onward. Phytolacca acinosa. In: Manual of the alien plants of Belgium. Meise Botanic Garden. Available at: http://alienplantsbelgium.be/content/ phytolacca-acinosa (Accessed 15 February 2021).

Verloove F., Galasso G., Banfi E., Ardenghi N.M.G. 2010. Notula 34. Datura wrightii Regel (Solanaceae), p. 388. In: Nepi C., Peccenini S., Peruzzi L. (eds). Notulae alla flora esotica d'Italia: 2 (22-37). Informatore Botanico Italiano, 42(1): 369-389.

Vojík M., Sádlo J., Petrrík P., Pyšek P., Man M., Pergl J. 2020. Two faces of parks: sources of invasion and habitat for threatened native plants. Preslia, 92(4): 353-373. https:// doi.org/10.23855/preslia.2020.353

Waselkov K.E., Boleda A.S., Olsen K.M. 2018. A phylogeny of the genus Amaranthus (Amaranthaceae) based on several low-copy nuclear loci and chloroplast regions. Systematic Botany, 43(2): 439-458. https://doi. org/10.1600/036364418X697193

Williams P.A., Timmins S.M. 2003. Climbing spindle berry (Celastrus orbiculatus Thunb.) biology, ecology, and impacts in New Zealand. Wellington, New Zealand: New Zealand Government, Department of Conservation, $28 \mathrm{pp}$.

Wyrzykiewicz-Raszewska M. 2009. Phytolacca acinosa Roxb. - a new anthropophyte in the flora of Poland. Steciana, 13: 3-7 [Roczniki Akademii Rolniczej w Poznaniu, vol. 388]. Available at: http://merlin.up.poznan. $\mathrm{pl} /$ steciana/wp-content/uploads/2014/03/13_Stec 1 Wyrz.pdf

Zaniewski P.T., Wołkowycki D., Szczepkowski A., Otręba A., Zaniewska E., Kębłowska A. 2020. Patterns of invasion, biology and ecology of Erechtites hieraciifolia in the northern expansion range in Europe (C and NE Poland). Baltic Forestry, 26(1): art. 409 (12 pp.). https://doi. org/10.46490/BF409

Zaya D.N., Leicht-Young S.A., Pavlovic N.B., Feldheim K.A., Ashley M.V. 2015. Genetic characterization of hybridization between native and invasive bittersweet vines (Celastrus spp.). Biological Invasions, 17(10): 2975-2988. https://doi.org/10.1007/s10530-015-0926-Z

Zaya D.N., Leicht-Young S.A., Pavlovic N.B., Hetrea C.S., Ashley M.V. 2017. Mislabeling of an invasive vine (Celastrus orbiculatus) as a native congener (C. scandens) in horticulture. Invasive Plant Science and Management, 10(4): 313-321. https://doi.org/10.1017/inp.2017.37

Zieliński J., Petrova A., Natcheva R. 2012. New species for the Bulgarian flora. Phytologia Balcanica, 18(2): 197204. Available at: http://www.bio.bas.bg/ phytolbalcan/ PDF/18 2/18 2 13 Zielinski \& al.pdf

Zhang Z.-X., Funston A.M. 2008. Celastrus. In: Wu Z.-Y., Raven P.H., Hong D.-Y. (eds.). Flora of China, vol. 11. Beijing: Science Press \& St. Louis: Missouri Botanical Garden Press, pp. 466-474.

Recommended for publication by F. Verloove 
Мосякін С.Л., Мосякін А.С. 2021. Ботаніка під час локдауну 2020 року: деякі варті уваги знахідки адвентивних рослин у місті Києві та Київській області. Украйнський ботанічний журнал, 78(2): 96-111 [In English].

Інститут ботаніки ім. М.Г. Холодного НАН України, вул. Терещенківська 2, Київ 01601, Україна: С.Л. Мосякін. Українське ботанічне товариство, вул. Терещенківська 2, Київ 01601, Україна: А.С. Мосякін.

Реферат. Повідомляється про варті уваги знахідки 11 видів адвентивних рослин у Києві та Київській області, виявлені переважно протягом 2020 р. Зокрема, знайдені нові локалітети таких видів: Amaranthus spinosus, Artemisia tournefortiana, Chenopodium ucrainicum, Celastrus orbiculatus, Datura innoxia, Dysphania ambrosioides, Erechtites hieraciifolius, Mesembryanthemum $\times$ vascosilvae $(M$. cordifolium $\times$ M. haeckelianuт; нещодавно описаний як Aptenia ×vascosilvae, тут наведений вперше для України; раніше цей декоративний гібрид помилково наводився під назвою A. cordifolia), Parietaria officinalis, Phytolacca americana, Thladiantha dubia. Вказано на присутність на території України декількох додаткових видів, зокрема Datura wrightii та Phytolacca acinosa s.1. (incl. P. esculenta), які можуть траплятися як здичавілі біля місць їхнього культивування; ці види можуть бути сплутані зі спорідненими видами D. innoxia та P. americana, відповідно. Відмічено зрослу роль ергазіофітів (видів, здичавілих з культури) у сучасних процесах формування адвентивної флори України.

Ключові слова: Amaranthus, Artemisia, Celastrus, Chenopodium, Datura, Dysphania, Erechtites, Mesembryanthemum, Phytolacca, Київ, Україна, флора, чужорідні види 

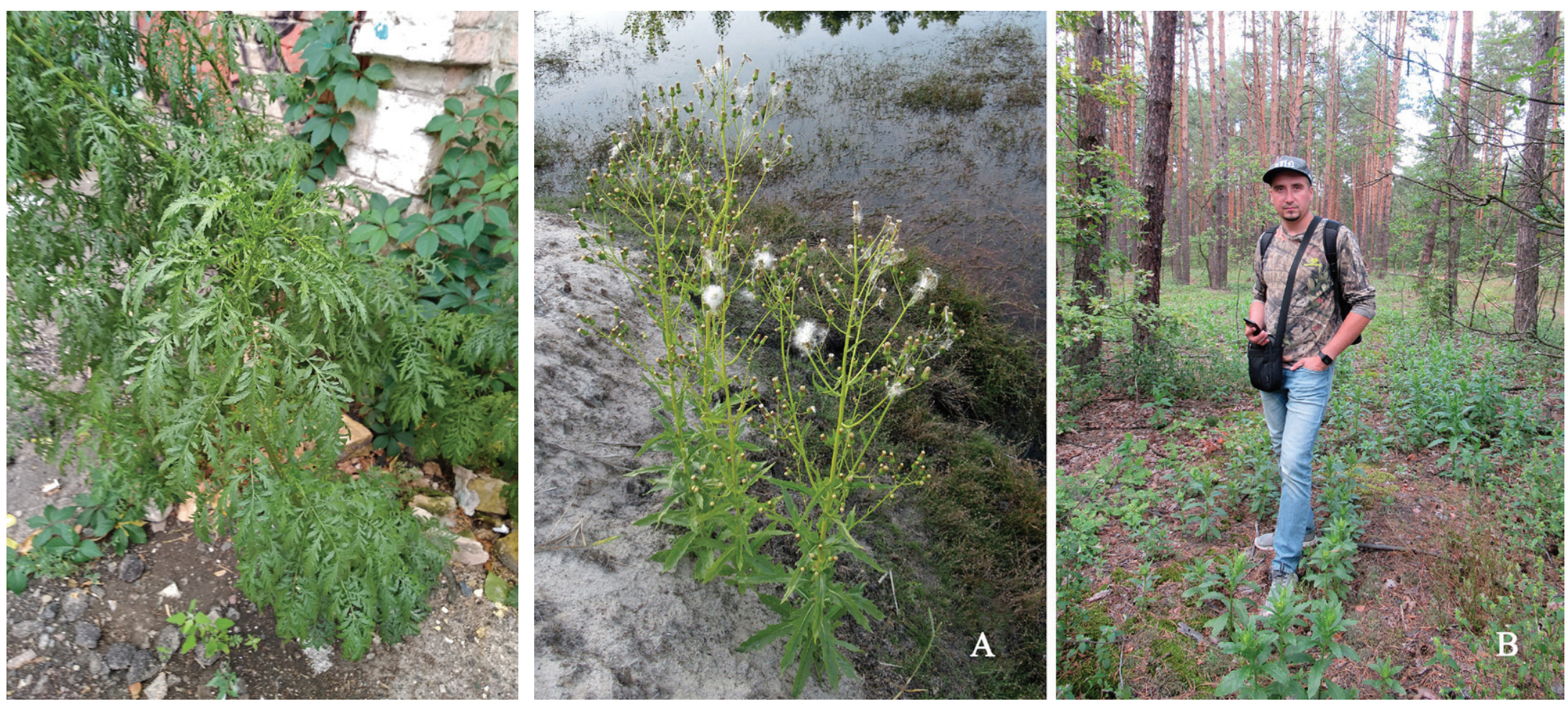

Fig. E1. Artemisia tournefortiana, Kyiv, Turgenevska Fig. E2. Erechtites hieraciifolius. A: at a forest lake, Kyiv Region, near Sukholuchchya, 12 September 2020 ; Street, 22 July 2020 

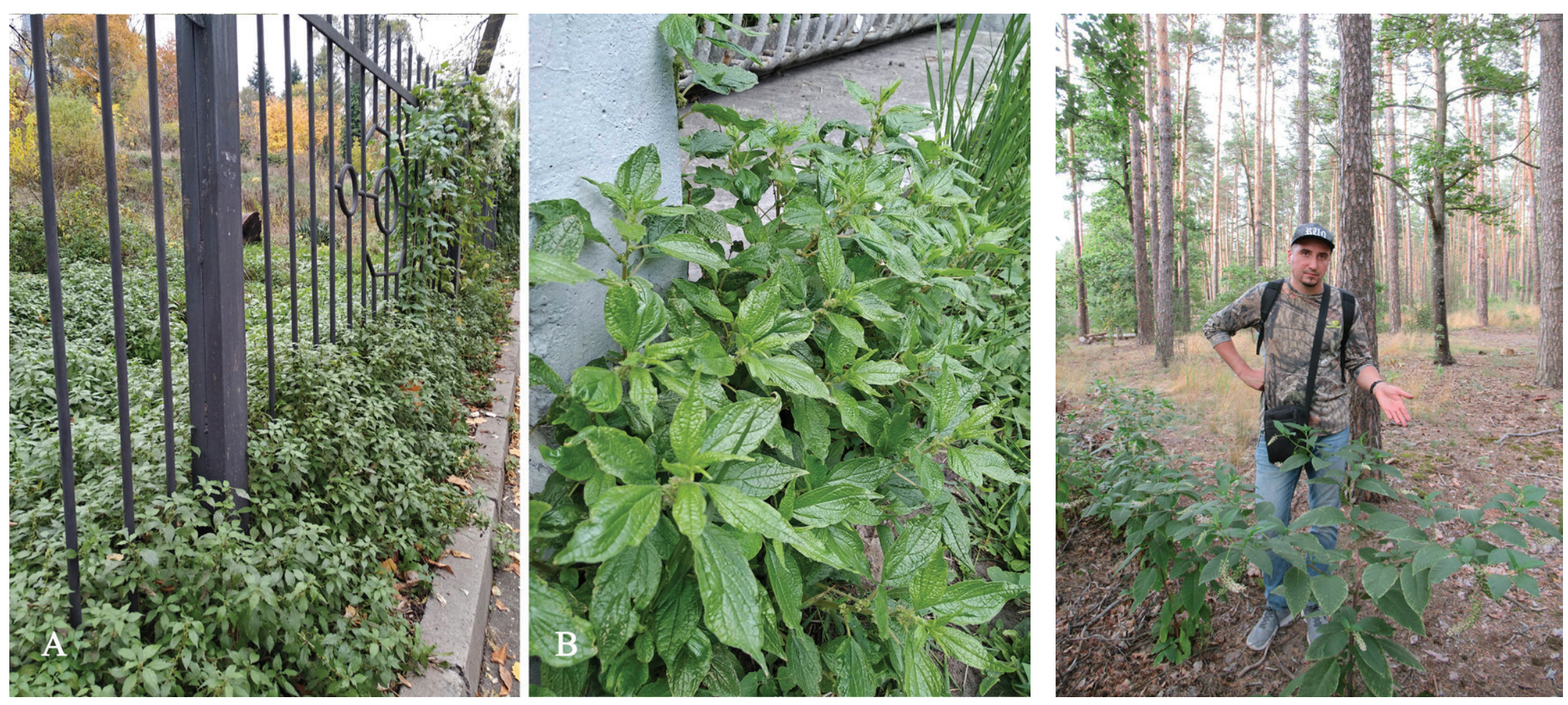

Fig. E3. Parietaria officinalis. A: Kyiv, Fomin Botanical Garden, 13 November 2020; B: Kyiv, Bohdan Havrylyshyn Street, 2 May 2020

Fig. E4. Phytolacca americana, Pushcha-Vodytsya Forest, 2 August 2020 

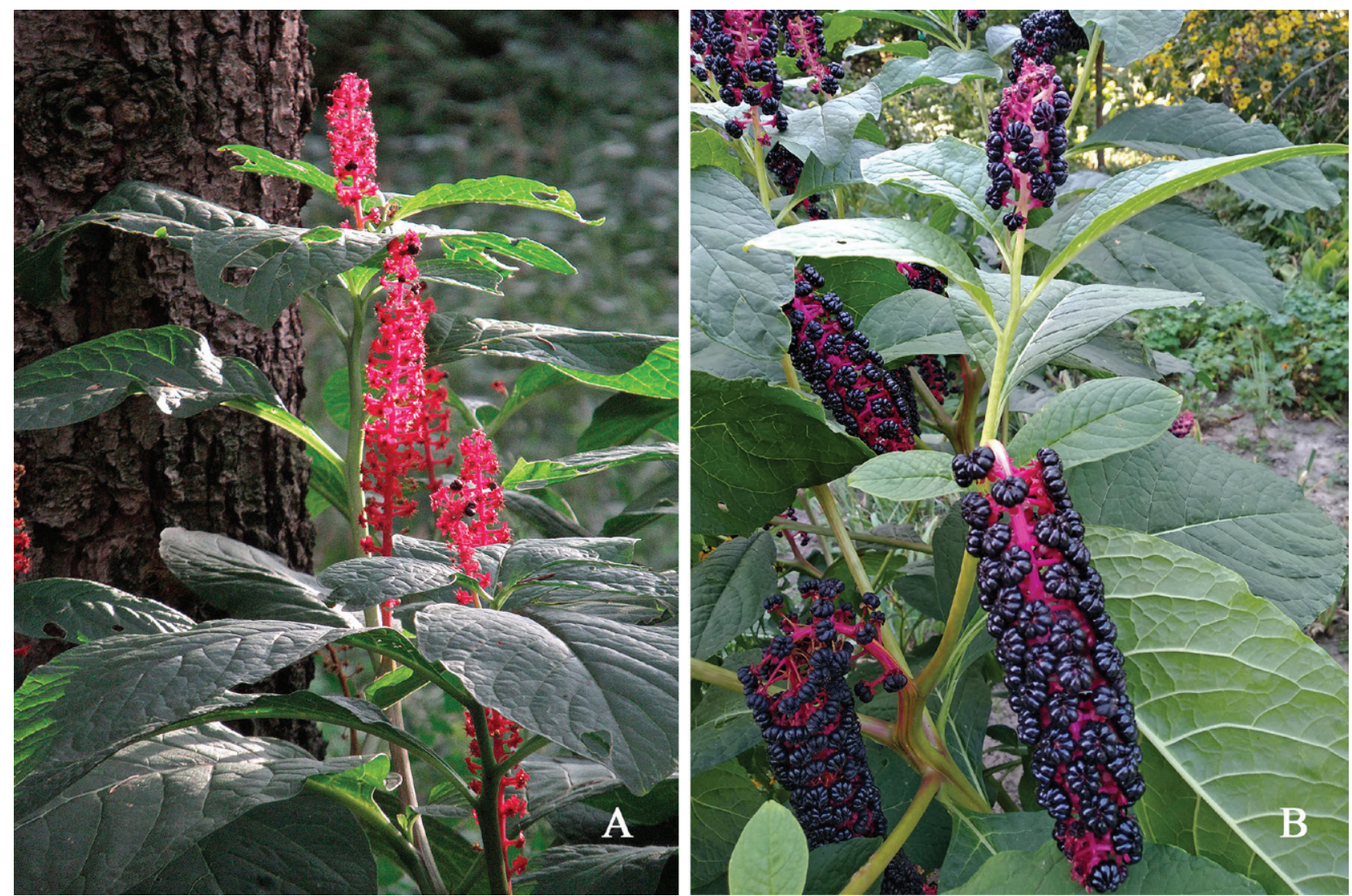

Fig. E5. Phytolacca acinosa s. 1., cultivated. A: Syrets Arboretum, 6 September 2020: B: Kyiv Region, Hrebinky, 25 August 2019

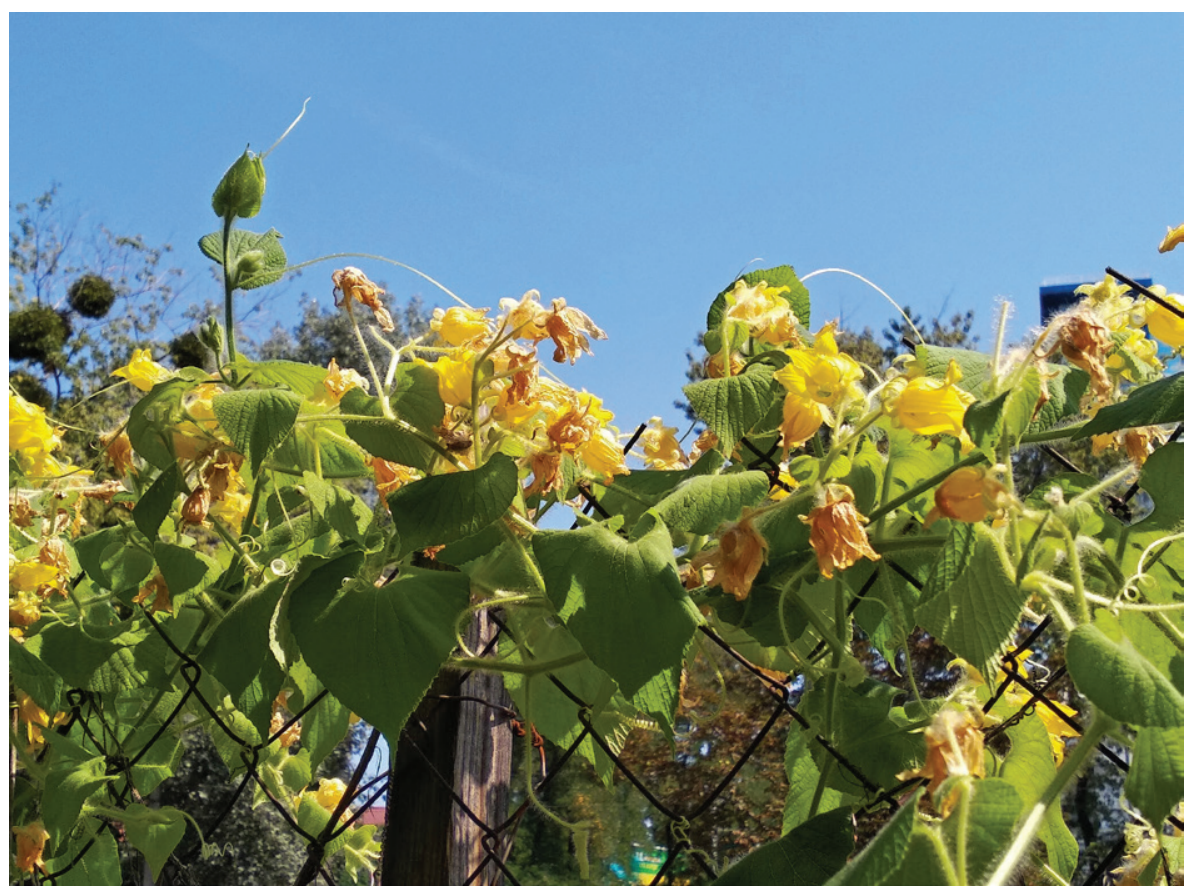

Fig. E6. Thladiantha dubia overgrowing a fence, Kyiv, Lukianivka, 7 August 2020 